\title{
Which Type of Trust Matters?: Interpersonal vs. Institutional vs. Political Trust
}

\author{
In Do Hwang*
}

The views expressed herein are those of the authors and do not necessarily reflect the official views of the Bank of Korea. When reporting or citing this paper, the authors' names should always be explicitly stated.

* Economist, Economic Research Institute, The Bank of Korea, Tel: +82-2-759-5362, E-mail: hid@bok.or.kr

I thank Daron Acemoglu, Dan Bernhardt, Jeffrey R. Brown, Hyun Kyung Choi, Woong Yong Park, Rebecah Pulsifer, David Quigley, Luis Felipe Saenz Munoz, Wook Sohn, Geunhyung Yim, and an external reviewer of the BOK Working Paper for their valuable comments and suggestions. I also thank Jan Delhey, Kenneth Newton, and Christian Welzel for the provision of the radius-adjusted trust index in their paper (2011). The views in this paper are solely the responsibility of the author and should not be interpreted as reflecting the views of The Bank of Korea. 


\section{Contents}

I . Introduction …………………………………………………… 1

II. The Existing Studies on Trust ………………………... 5

III. Trust Data ……………………………………………… 7

IV. Cross-sectional Analysis ………………………………... 12

V. Panel Data Analysis …………………………………. 22

VI. Interpretation and Discussion ……………………….... 29

VII. Conclusion ……………………………………………… 34

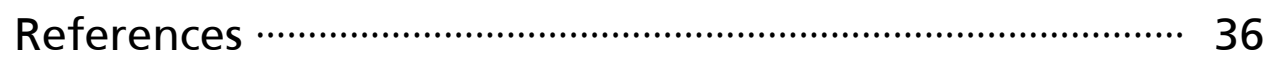

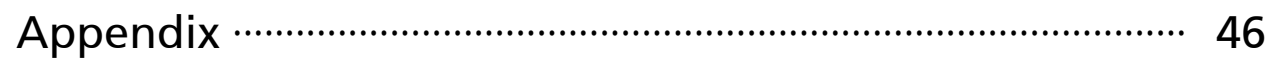




\section{Which Type of Trust Matters?: Interpersonal vs. Institutional vs. Political Trust}

Although an increasing number of studies demonstrate the importance of trust in economic growth, they only focus on interpersonal trust. This paper considers various types of trust including interpersonal trust (i.e., trust in people), institutional trust (e.g., trust in the fair administration of justice, or trust in the protection of property rights), and political trust (e.g., trust in government or political parties), and investigates their impacts on growth. Using novel cross-country survey data, this paper finds that institutional trust is most robustly related to the economic growth in a cross-section of 46 countries. This paper also shows that there is a causal relationship between institutional trust and growth using panel data from those 46 countries. Hence, in contrast with the previous trust literature which focuses on trust in "people" as a "time-invariant cultural feature," this paper stresses trust in "social system" as an "institutionsdependent feature."

Keywords: Institutions and economic growth, Trust, Social capital

JEL Classification: O17, P16, Z13 
"Commerce and manufactures can seldom flourish long in any state which does not enjoy a regular administration of justice, in which the people do not feel themselves secure in the possession of their property, in which the faith of contracts is not supported by law, and in which the authority of the state is not supposed to be regularly employed in enforcing the payment of debts from all those who are able to pay." (Adam Smith, Wealth of Nations (1776), italics added)

\section{Introduction}

Consider these two scenarios:

(i) I trust you since you are a trustworthy person (i.e., because of your type);

(ii) I trust you since I know that you will be punished if you break the rule. (i.e., because of the incentive structure you face);

They are all referring to trust, but in a different context. Sources of trust can be not only the inborn disposition of a person, but also reliable social systems (Hardin, 1991; Delhey \& Newton, 2003; Wang \& Gordon, 2011) and political organizations (Newton, 1999, 2001). However, this multi-dimensional feature of trust has been neglected in almost all of the existing empirical studies on trust ${ }^{1)}$ or, more broadly, social capital. That is, most empirical studies on trust and growth only deal with interpersonal trust without considering trust in institutions or political organizations. What they use as a measure of trust is based on one question, "Generally speaking, would you say that most people can be trusted or that you need to be very careful in dealing with people?", hereafter called the most people question. The lack of research that considers various aspects of trust is surprising, given that the nature of trust is directly connected to the question of what determines growth.

This paper takes various types of trust into account, including interpersonal, institutional and political trust, and investigates their impacts on economic growth. Using a novel cross-country survey conducted by the International

1) See Knack and Keefer (1997), Whiteley (2000), Zak and Knack (2001), Dincer and Uslaner (2010), and Algan and Cahuc (2010). They demonstrate that interpersonal trust (measured by the most people question) has a causal impact on growth. 
Institute for Management Development (IMD) and the existing World Values Survey (WVS), this paper measures various types of trust. More specifically, institutional trust is measured by businessmen's confidence in the fair administration of justice and in the protection of property rights; interpersonal trust is measured by the most people question; political trust is measured by respondents' confidence in their government and political parties.

In response to the key research question, "which type of trust matters for growth?", this paper finds that institutional trust is most robustly related to growth in a cross-section of 46 countries: results of OLS and 2SLS indicate that institutional trust is consistently significant in explaining the growth for the period of 1997-2012 after controlling for the effects of initial income, relative prices of investments, and education. This result remains robust after the inclusion of additional control variables (government share of GDP, trade openness, and regional dummy variables for East Asia and Nordic countries) and the application of different estimation methods such as quantile regression.

In the next section, this paper focuses on institutional trust and examines if there is a causal relationship between institutional trust and growth. Most of the previous research on trust cannot make causal arguments since the cross-sectional analysis employed does not control for time-invariant factors or country fixed effects. Therefore, it is impossible to identify whether the difference in growth is caused by trust or other factors: there could be a third factor affecting trust and growth simultaneously. Using the time variation of institutional trust uniquely provided by the IMD data, this paper employs the dynamic panel model to argue causality. Specifically, Arellano and Bond's (1991) difference GMM model is applied to resolve the endogeneity issue. The result of the model, which uses four-year non-overlapping averages for 46 countries for the period of 1993-2012, confirms the causal relationship. Consequently, this paper establishes the causal link between institutional trust and growth. Overall, this study bridges the gap between the literature on trust and the literature on institutions: (i) the paper stresses the role of formal institutions in the formation of trust, compared with the literature on interpersonal trust. (ii) the paper emphasizes the role of subjective perceptions 
or trust, compared with the literature on the quality of institutions and growth.

This paper is related to the three strands of literature. First, this paper is linked to the general social trust literature that investigates the role of trust in economic growth (Putnam, 1993; Knack \& Keefer, 1997; La Porta, Lopez-de-Silanes, Shleifer, \& Vishny, 1997; Whiteley, 2000; Zak \& Knack, 2001; Woo, Kim, \& Jang, 2007; Dincer \& Uslaner, 2010; Algan \& Cahuc, 2010; Tabellini, 2010; Bjørnskov \& Méon, 2013; Horváth, 2013). This paper adds to the existing literature by considering various types of trust and investigating each type's importance in explaining economic performance. While previous studies have focused on trust in "people", the result of this paper emphasizes the significance of trust in "institutions" regarding economic activities. For example, when both the interpersonal trust measure and institutional trust indices are included as explanatory variables for growth, only institutional trust indices are found to be significant. This paper also demonstrates the causal relation between institutional trust and growth. To the best of my knowledge, only Algan and Cahuc (2010)2) utilize the time variation of trust and rigorously examine the causal relationship; but their study overlooks other types of trust except for interpersonal one.

Second, this paper is related to the literature stressing the role of "institutions" associated with "property rights" and "rule of law" in economic growth, such as North (1990), Knack and Keefer (1995), Acemoglu, Johnson and Robinson (2001, 2002, 2005), Rodrik, Subramanian and Trebbi (2004), Haggard and Tiede (2011), Acemoglu and Robinson (2012), and Shin, Noh, Lee and Moon (2014). Studies on corruption and growth, conducted by Mauro (1995) and Glaeser and Saks (2006), are also connected with this paper. The monumental studies of Barro (1991, 1996, 2003) and Barro and Sala-i-Martin (2004) are relevant as well, which provide a comprehensive picture of growth determinants including institutions and political stability. This paper is

2) The results in this paper are not inconsistent with Algan and Cahuc (2010), who report that "changes in political institutions do not play a significant role [in growth] when inherited trust and initial economic development are controlled for (p. 2077)" since, in their study, political institutions are measured by composite indicators of democracy (Polity2 from the Polity IV dataset), not by the indicators related to the rule of law or property rights. 
consistent with these studies in that it highlights the significant impact of institutional trust on growth. The difference between this paper and the previous work is that the former focuses on the "perception" of economic agents, named institutional trust here, not on the quality of institutions, per se. Rothstein (2000) illustrates such difference clearly: "it is not the formal institutions, per se, that can solve the problem of credible commitment, but instead, the actor's 'cognitive maps' about how trustworthy the actors are in operating these institution" (p. 483). This paper provides suggestive evidence that such "cognitive maps" or subjective confidence affect economic activities. More specifically, when both the quality of institutions measure (PRS rule-of-law) and institutional trust indices (Justice, PropertyRights, \& LegalSystem) are included as explanatory variables for economic growth, only institutional trust indices are found to be statistically significant both in the cross-section and panel of countries. Institutional trust indices of this paper are different from the quality of institutions measures (e.g., PRS rule-of-law indicator, ICRG risk of expropriation indicators and BERI contract enforceability indicators) in that the institutional trust indices capture businessmen's pure confidence. While ICRG, PRS and BERI indicators are based on a total of 50 100 experts' ratings on worldwide countries and are subject to peer- or expert- review process, the IMD institutional trust indices are pure survey results targeting a total of 4,000 business executives who really lived or worked in the country for the past year. As a result, the IMD institutional trust indices have significant time variation while ICRG, PRS and BERI data on the quality of institutions have little time variation. Figure $\Pi$ in Section $V$ illustrates the difference.

Third, this paper is also linked to the literature on 'political trust' and trust in the government. Following Newton (1999, 2001), Mishler and Rose (2001), Keele (2007), and Tao, Yang, Li and Lu (2014), this paper adopts the view that political trust has different features from other types of trust. Political trust is estimated to have a less robust relationship with growth than institutional trust in the 46 countries, suggesting it is not much directly related to economic activities. 
This paper is organized as follows. Section II discusses theoretical framework and summarizes existing studies. Section III presents the trust data and shows how three types of trust are correlated. Section IV and V perform a cross-sectional and panel data analysis, respectively. While the cross-section analysis investigates how trust is correlated with long-run growth (16-year average growth rate), a panel data analysis examines causal effects on short-to-medium term growth (4-year average growth rate) when country fixed effects and endogeneity issues are controlled. Section VI interprets the results and offers discussions to advance our understanding of institutional trust. Section VII presents the conclusion.

\section{The Existing Studies on Trust}

\section{Theoretical framework: how trust affects growth?}

The trust literatures suggest various transmission mechanisms through which trust stimulates economic growth. First, trust lowers transaction costs and stimulates investment. Agents in a high trust society do not waste resources in verifying the truthfulness of their trade partners (Zak \& Knack, 2001) or protecting private property (Whiteley, 2000). Trust is especially important in trust-intensive contracts such as financial contracts (Guiso, Sapienza, \& Zingales, 2004, 2008a) and international trade (Guiso, Sapienza, \& Zingales, 2009). Second, trust can foster and accumulate human capital by providing stronger incentives (Knack \& Keeper, 1997) and by lubricating the process of education in which both competition and cooperation are needed (Bjørnskov, 2009, 2012; Dearmon \& Grier, 2011; Bjørnskov \& Méon, 2013). An invention and the diffusion of innovation can be done more easily under mutual trust, which leads to cooperation, frequent communication (Isham, 2000) and learning (Whiteley, 2000). Third, trust can enhance the quality of governance (Helliwell \& Putnam, 1995; Nannicini et al., 2013; Knack, 2002). Trust can lead to higher accountability in decision making and reduce the principal-agent problem because agents try to live up to others' expectations. And trust in other parties makes it easy to reach an agreement when political parties are polarized. 


\section{Empirical results on trust and growth}

Most empirical studies conducted at the regional or national level support the idea. Knack and Keefer (1997) implement cross-sectional growth regressions and show that the trust index has significant explanatory power in explaining the growth rates of 29 countries during 1980-1992. Zak and Knack (2001) analyze 41 countries' cross section data during 1970-1992, finding that the trust index has a significant effect on growth rates as well as on the Investment/GDP ratio. Dincer and Uslaner (2010) analyze the 2-period panel data of 43 US states, showing that states with a higher level of trust grow faster than those with a low level of trust. Algan and Cahuc (2010) rigorously examine the causal effects of trust on growth and confirm them using the time variation of inherited trust. Tabellini (2010) also finds a causal relationship in a study on European regions. Bjørnskov and Méon (2013) claim that trust spurs economic development by improving human capital and institutions. Horváth (2013) shows that trust is a robust determinant of growth in the framework of Bayesian model averaging.

Those empirical papers, however, do not consider various types of trust. All of them use one trust index, which is based on the most people question. ${ }^{3)}$ The definition of trust, though, is much more comprehensive than the idea the most people question captures. I will discuss it in the next section.

3) Also note that an increasing number of studies are challenging the validity of the most people question as a measure for the general level of trust. First, the most people question suffers from the radius problem. Sturgis and Smith (2010), and Delhey, Newton and Welzel (2011) show that (i) a substantial number of respondents in WVS respond to the most people question based on their trust in friends or neighbors, but not based on unknown people (i.e. the radius is too small) and (ii) the radius of "most people" differs a lot across nations. Second, responses to the most people question are contaminated by other factors such as the degree of risk aversion of respondents (Sapienza et al., 2013). Third, experimental studies often show contradictory results on the interpretation of the most people question. Glaeser et al. (2000), and Lazzarini, Madalozzo, Artes and Siqueira (2005) suggest that the most people question measures "trustworthiness" of other people, not "trusting behavior" (i.e., one's own tendency to trust), while the study of Bellemare and Kröger (2007) indicates that the question does measure "trusting behavior." 


\section{Trust Data}

\section{Definition and classification of trust}

The trust literature suggests that the meaning of trust is not a clear-cut or limited concept. Rather, it is a multi-dimensional and comprehensive concept (Williamson, 1993; Mcknight \& Chervany, 1996; Newton, 2001; Delhey \& Newton, 2003). Based on the previous literature, I classify the concept of trust in the following ways:

(i) By distance of trust (or radius of trust), i.e., particularized trust vs. generalized trust. Particularized trust is trust in people with whom he/she is familiar (e.g., family, friend, neighborhood), whereas generalized trust refers to trust in anonymous citizens or strangers (Uslaner, 2002; Bjørnskov, 2007). Of the two, generalized trust is more related to economic performance since economic transactions typically involve an anonymous counterpart, and generalized trust reduces monitoring and enforcement costs in that case.

(ii) By sources (object) of trust, i.e., interpersonal trust vs. institutional trust (also called system trust) vs. political trust. Interpersonal trust refers to trust in 'people' while institutional trust refers to trust in the "social system" or the "administration of social norms" (Shapiro, 1987; Hardin, 1991; Yamagishi, Cook, \& Watabe 1998; Rothstein, 2000; Wang \& Gordon, 2011). In game theory terminology, interpersonal trust is associated with the 'type' of the other players (or his own disposition to believe other players), while the institutional trust is related to the rules of the game.4) In the language of Yamagishi and Yamagishi

4) In the strict sense, institutional trust can be defined as trust coming from institutions which affect the cost of betrayal, and hence, affect the sender's belief in the receiver's trustworthiness in the trust game. (In the game, a sender decides how much money to pass to a receiver and the receiver decides how much of this to return to the sender. The degree of trust of a sender is often measured by the amount sent by the sender and the trustworthiness of a receiver is measured by the amount of money returned by the receiver in the trust game experiment).

Put another way, what I call institutional trust is the trust coming from an incentive structure that subjects experienced in the first phase of the trust game in the experimental setting of Bohnet and Huck (2004). Their study provides experimental evidence that institutions do affect the intrinsic level of trust and trustworthiness in the framework of the trust game. Specifically, they show that subjects' propensity to be trustworthy in the second phase of the game is affected by the institutions they are exposed to in the first 
(1994), interpersonal trust is associated with "benevolence," while institutional trust is based on "deterrence." Political trust is associated with confidence in a rule-maker of a game and is defined by trust in a political organization or leader (Newton, 1999, 2001). Hence, it is different from interpersonal or institutional trust. For example, Newton (2001) reports that political trust is learned indirectly, usually through the media, whereas interpersonal trust is learned directly. 5 )

\section{Trust data}

To capture various types of trust, this paper introduces the cross-country survey data conducted by the IMD, which have been published in the World Competitiveness Yearbook every year since mid-1990s. This paper also uses the WVS data. The survey items related to trust are specifically as follows:

(IMD)

- "There is full confidence in the fair administration of justice in the society" $(6,5, . ., 1)$ Juctice

- "There is full confidence among people that their person and property is protected" $(6,5, . ., 1)$ PropertyRights

- "The government adapts its policies to new economic realities effectively" $(6,5, . ., 1)$ GovernmentPolicy

- "Political parties understand today's economic challenges" $(6,5, \cdots, 1)$ PoliticalParty1

phase of the game (p. 363). Similarly, Bohnet and Baytelman (2007) show that institutions increasing the cost of betrayal enhance subjects' willingness to trust and be trustworthy.

5) Note that there are various ways to classify trust. For example, it can be classified by concept of trust, i.e., benevolence-based trust vs. honesty-based trust vs. ability-based trust. Benevolence-based trust implies the belief that a person will care about others' welfare. Honesty-based trust is the belief that the counterpart will tell the truth, whereas ability-based trust refers to the confidence that the counterpart will do successfully what they need. (McKnight \& Chervany, 1996; Yamagishi \& Yamagishi, 1994; and Das \& Teng, 2001) 
(WVS)

- "Generally speaking, would you say that most people can be trusted or that you need to be very careful in dealing with people? (Most people can be trusted / Have to be very careful)" ............................................. MostPeople

"For each one, could you tell me how much confidence you have in them?"

- "The legal system (A great deal/ quite a lot/ Not very much / None at all)"

LegalSystem

- "The government (A great deal/ quite a lot/ Not very much / None at all)"

Government

- "Political parties (A great deal/ quite a lot/ Not very much / None at all)"

PoliticalParty2

The IMD surveys executives (top and middle management) of international companies in 46 countries to compare the competitiveness of each country while the WVS asks representative national samples of individuals across about 50 countries in each wave to explore people's values and beliefs. Respondents of the IMD surveys are asked to evaluate the country in which they work or have resided during the past year, whereas respondents of the WVS are asked to evaluate the country where they are living now. 6 ) The 1996 IMD data are based on 4,000 responses from executives, whereas the 1995-1998 WVS (conducted in mostly 1995-1997) data are based on 60,000 responses from individuals. Therefore, on average, the IMD trust measure for a country is based on 87 respondents' answers, while the WVS trust index is based on 1,100 respondents' answers. One issue surrounding the IMD data is that it may have winner's bias since the survey only targets top- and middle-management of businesses. Fortunately, the degree of the bias is found to be negligible in the

6) The IMD survey questions are targeted for the top and middle management, who are nationals or expatriates, located in local and foreign enterprises in the country, which, in general, have an international dimension. Respondents are asked to evaluate the present and expected conditions in six degrees (1-2-3-4-5-6) for the country in which they work or have resided for the past year. A sample size of respondents in each industry is selected, which is proportional to the GDP breakdown of the economic sectors of the economy. 


\section{between-country level.7)}

Since the IMD trust indices have 0-10 scale8), WVS measures are also rescaled to the level of $0-10$. High index levels indicate high trust levels. These indices can reflect various kinds of trust. Justice, PropertyRights and LegalSystem measure 'institutional trust' and 'generalized trust' because they are related to the trustworthiness of the "social system" which affects the incentive structure of "unknown" people in society. This grouping is in line with the study of Haggard and Tiede (2011) which reports the "rule-of-law" affects economic activities by providing the "protection of property rights." Three indices are also associated with "inclusive economic institutions that enforce property rights create a level playing field" (Acemoglu \& Robinson, 2012, p. 429). MostPeople may capture both particularized trust and generalized trust because the most people

7) The existing studies show that trust tends to be high among 'winners' in society (Putnam, 2000: 138; Newton, 2001: 204; Alesina \& Ferrara, 2002; Delhey \& Newton, 2003), indicating that businessmen's level of trust can be quite different from that of the general population. One feasible way to examine this issue is to see whether there is a systematic difference between senior businessmen's views and all agents'views. In contrast to the IMD survey, the WVS measures all individuals' views on trust and it also provides information on the respondents' job. The below table shows the correlation coefficient between the 'trust index from senior businessman only' and the 'trust index of all individuals' in the WVS. Although senior businessmen represent only $6 \%$ of all respondents, their views are strongly associated with all agents' views $(=0.88 \sim 0.93$, significant at $1 \%)$. This result says that, although there could be a difference in the level of trust between the public and a small number of winners within a country, when comparing the same groups between countries, the views of successful business individuals provide useful information on the country-level difference in trust.

Trust Index based on Responses of Senior Businessmen Only' and 'Trust Index from All Individuals' in 55 Countries

\begin{tabular}{c|cccc}
\hline & Most People & Legal System & Government & PoliticalParty2 \\
\hline Corr. coef & $0.91^{* * *}$ & $0.88^{* * *}$ & $0.93^{* * *}$ & $0.93^{* * *}$ \\
\hline
\end{tabular}

Note: This table demonstrates that the trust measure based on all individuals' views and that based on senior businessmen's views are not systematically different in the cross-section of 55 countries where the third wave (1995-1998) WVS is conducted.

8) The IMD data is based on the average value of respondents' assessment which has a scale of 1-6 (6 indicates the most positive perception). Then the data is converted from a 1-6 scale to a $0-10$ scale by "X*2-2", where $\mathrm{X}$ is the average value. Officially, the IMD releases the $0-10$ scale data.

In the case of MostPeople from the WVS, the original value is calculated by " $100+$ Yes - No" and has a 0-200 scale. (Yes=the proportion of people who chose 'Most people can be trusted', No=the percentage of people who responded 'Have to be very careful'). The author normalizes the data to have a mean of 5 and a standard deviation of 2, so that most of the values are on the scale of 0-10. In the case of LegalSystem, Government, and PoliticalParty2, the author calculates the average value of respondents' assessment which has a scale of 1-4 (4 indicates full confidence). Then, the author normalizes the data to have a mean of 5 and a standard deviation of 2 , so that most of the values are on the $0-10$ scale. 
question is exposed to the radius problem (Sturgis and Smith (2010), and Delhey, Newton and Welzel (2011) show that a substantial fraction of the WVS participants responds to the most people question based on their trust in friends or neighbors while others respond to the question based on their trust in unknown people -i.e., the radius of trust is different). GovernmentPolicy, PoliticalParty1, Government, PoliticalParty2 reflect trust in political organizations. Of those, GovernmentPolicy and PoliticalParty1 are closely associated with 'abilities' of the organization in managing economic matters.

\section{Correlations: is the classification appropriate?}

The correlation of various trust indices in Table A3 (Appendix) suggests that, although the correlations are affected by the sources of the survey, overall, the classification of trust indices is appropriate. Two IMD institutional trust indices (Justice \& PropertyRights, $\rho=0.87$ ) and two WVS political trust indices (Government \& PoliticalParty2, $\rho=0.76$ ) show strong correlation with each other, respectively, hinting that they are capturing the same type of trust; LegalSystem, the only measure which is classified as institutional trust among the WVS indices, is correlated with IMD institutional trust $(\rho=0.38 \sim 0.45)$, but not with IMD political trust; similarly, GovernmentPolicy from the IMD is correlated with only Government from the WVS.

It is worthwhile to note that MostPeople does not show a strong relationship with the two political trust indices (Government \& PoliticalParty2) or with institutional trust (LegalSystem). ${ }^{9)}$ This indicates that MostPeople is capturing different aspects of trust from the institutional or political trust indices in the sample countries. ${ }^{10)}$

9) The individual level study by Alesina and Ferrara (2002) also reports a weak association between trust in most people and trust in an institution (p. 217).

10) The fact that MostPeople is closely associated with the IMD institutional trust indices (Justice, PropertyRights), but not with the WVS institutional trust index (LegalSystem), indicates that there could be heterogeneity even among the institutional trust indices. This could be attributed to the fact that the IMD survey asks a deeper question than the WVS does. That is, the IMD survey asks how well the value that institutions pursue is realized in the society, while the WVS asks the reliability of the legal institution itself. To avoid too complex classifications, this paper classifies them as the same type of trust. 
The principal component analysis provides additional evidence that the classification is legitimate. The left panel of Table A4 (Appendix) shows that the first component of each type of trust explains 70\%, 68\%, 93\% of the total variance of institutional trust indices, ability-based political trust indices and overall political trust indices, respectively. This shows that, although there are two or three indices in each group, most of their variances can be explained by one important component. Panel B of Table A4 indicates that the eight trust indices cannot be combined into or converged to one concept of trust. The first factor explains only $42 \%$ of the total variance. Two or three factors are needed to explain $67 \%$ or $79 \%$ of the total variance.

\section{Cross-sectional Analysis}

\section{Estimation strategy \& Data}

A Barro-type growth model is employed to examine which type of trust has significant explanatory power on long-run growth. To get a reliable result, this paper adopts the following estimation strategy from Kumar and Woo (2010).

First, to reduce the uncertainty associated with control variables ${ }^{1}$ ), control variables are selected among robust determinants of growth verified in the study of Sala-i-Martin et al. (2004). They are "the relative price of investment, primary school enrollment ${ }^{12)}$ and the initial level of real GDP per capita" (abstract) and other notable variables reported are regional dummies, trade openness and the

11) Note that results of the growth regression are found to be sensitive to other control variables included in the model (Levine and Renelt, 1992; Sala-i-Martin, 1997). Growth theory, however, does not explicitly suggest which control variable researcher should include as different growth theories are compatible with each other (Barro \& Sala-i-Martin, 2004, p. 541).

12) In the case of schooling data, the 'secondary school enrollment rate' is used because the 'primary school enrollment rate' has a very small variation in the 46 countries. In the 46 countries analyzed, the 'primary school enrollment rate' in 1995 has a mean of $91.8 \%$ and a standard deviation of $9.4 \%$, while the 'secondary school enrollment rate' has a mean of $60.9 \%$ and a standard deviation of $17.8 \%$. Because the goal of this paper is to figure out differences in growth rates across countries, the secondary school enrollment rate is used in order to better capture the differences in schooling across countries. 
government share of GDP. The first three variables will be included in the baseline regression while the other variables will be included in the regressions for robustness checks. The inclusion of trust can be justified because trust, which received attention only after the late 1990s, is not covered in the research of Sala-i-Martin et al. (2004). Panel A of Table A2 (Appendix) presents the summary statistics of the cross-section data set: 46 is the largest number of countries for which both IMD data and WVS data are available. Specifically, equation (1) is estimated:

$$
\text { Average growth rate }_{1997-2012 i}=\alpha+\beta_{1} x_{1 i}+\cdots+\beta_{k} x_{k i}+\gamma \text { trust }_{i}+e_{i} \ldots \ldots . .
$$

Second, to reduce reverse causality, which may arise when high growth enhances trust, pre-determined values are used as explanatory variables. Specifically, this paper uses trust indices fielded in 1996 and explores their impact on the subsequent growth of real per capita GDP during 1997-2012. The dependent variable is set to the 16-year average growth rate so that it can represent long-run growth. Roughly speaking, the 16-year average growth rate reflects the average growth rate during 3.4 business cycles. ${ }^{13)}$ Hence, one can expect that the effect of economic crises is smoothed, such as the Asian financial crisis (1997-), the global financial crisis (2007-) and the European sovereign debt crisis (2009-).

Third, to reduce the possible endogeneity problem coming from a persistent variable that affects both trust and growth, an instrumental variable (IV) approach is also utilized. As an instrument for trust, "the proportion of people belonging to hierarchical religions" defined as Catholic and Islam as of 1970s is used. The relevance of the instrument is based on Putnam's (1993) insight that a hierarchical religion discourages the formation of trust by deterring "horizontal" ties between people, which is confirmed by the studies of Zak and

13) The duration of the business cycle (the average during 1854-2009) is 56.2 months in the case of the United States. 
Knack (2001), Berggren and Jordahl (2006), and Bjørnskov (2007). 14) The exogeneity of the instrument (or exclusion restriction) is based on the literature (Norland, 2003; Cavalcanti, Parente, \& Zhao 2007; Young, 2009; Durlauf, Kourtellos, \& Tan, 2012) that indicate religions are not directly related to economic growth. Although Barro and McCleary (2003) report that religion could affect economic growth, they stress what matters in growth is the extent of believing, not belonging to a particular religion. Becker and Wößmann's (2009) study reports that Protestantism is related to economic performance, creating another concern that the instrument might affect growth directly by lowering the proportion of Protestantism. However, this paper controls for the education channel, the major channel through which Protestantism affects economic prosperity as reported in the study. Hence, conditional on the education variable being included, the trust variable should not be correlated with the error term.15) Admittedly, if there are other channels through which religions affect economic activities, then the instrumental approach may not be valid. A further examination on the causal relationship is conducted in Section V, using different instrumental variables.

Both the education variable (school enrollment rate) and the trust variable are included as covariates in the primary specification because this paper assumes that the education and trust are distinct components of human capital (i.e., school enrollment rate as a quantitative factor and trust as a qualitative factor). ${ }^{16)}$ This issue will be further examined in the robustness check part.

14) Interconnections among religions, interpersonal trust, legal institutions, and political organizations presented in Alesina and Giuliano (2013) suggest that the proportion of hierarchical religions can be used as instruments of all three types of trust.

15) Another issue surrounding the hierarchical religion is that Islam is a good proxy for oil producing countries, which shows a different growth pattern from other countries. However, the result of 2SLS remains almost unchanged when two OPEC countries included in the sample of this paper (Indonesia and Venezuela) are excluded from observations. The other issue is that Catholic Southern Europe is hit by the sovereign debt crisis more seriously than the Protestant North. However, as this paper uses 16-year average growth rate, it is expected that the effect is smoothed substantially.

16) Although literatures (Bjørnskov, 2009, 2012; Dearmon \& Grier, 2011; Bjørnskov \& Méon, 2013) suggest that trust affects the economy by increasing human capital, the school enrollment rate might not be a unique good proxy for human capital. 


\section{BOK Working Paper No. 2017-15}

Table I : Trust and Growth: OLS Regressions (baseline)

\begin{tabular}{|c|c|c|c|c|c|c|c|c|}
\hline & (1) & (2) & (3) & (4) & (5) & (6) & (7) & (8) \\
\hline \multirow[t]{2}{*}{$\ln Y_{96}$} & $-0.960^{* *}$ & $-1.053^{* * *}$ & $-0.841^{* *}$ & $-0.722^{* *}$ & $-0.823^{* *}$ & $-0.603^{* *}$ & $-0.965^{* *}$ & $-0.606^{* *}$ \\
\hline & $(0.364)$ & $(0.387)$ & $(0.332)$ & $(0.292)$ & $(0.342)$ & $(0.268)$ & $(0.423)$ & $(0.269)$ \\
\hline \multirow[t]{2}{*}{ P_inv96 } & $-0.0162^{*}$ & $-0.0149^{*}$ & -0.0101 & $-0.0185^{* *}$ & -0.00946 & -0.00786 & -0.00535 & -0.00888 \\
\hline & $(0.00855)$ & $(0.00868)$ & $(0.0117)$ & $(0.00864)$ & $(0.00888)$ & $(0.00956)$ & $(0.0121)$ & $(0.00988)$ \\
\hline \multirow[t]{2}{*}{ Schoolg5 } & $0.0244^{* *}$ & $0.0306^{* * *}$ & $0.0324^{* * *}$ & $0.0215^{* *}$ & $0.0268^{* *}$ & $0.0230^{* *}$ & $0.0218^{* *}$ & $0.0228^{* *}$ \\
\hline & $(0.00946)$ & $(0.0106)$ & $(0.0101)$ & $(0.00938)$ & $(0.01000)$ & $(0.00856)$ & $(0.00871)$ & $(0.00837)$ \\
\hline \multirow[t]{2}{*}{ Justice 96} & $0.228^{* *}$ & & & & & & & \\
\hline & $(0.113)$ & & & & & & & \\
\hline \multirow[t]{2}{*}{ PropertyRights 96} & & $0.246^{* *}$ & & & & & & \\
\hline & & $(0.114)$ & & & & & & \\
\hline \multirow[t]{2}{*}{ LegalSystem $_{96}$} & & & $0.209^{*}$ & & & & & \\
\hline & & & $(0.115)$ & & & & & \\
\hline \multirow[t]{2}{*}{ MostPeople 96} & & & & 0.185 & & & & \\
\hline & & & & $(0.130)$ & & & & \\
\hline \multirow[t]{2}{*}{ [ GovernmentPolicy 96} & & & & & 0.136 & & & \\
\hline & & & & & $(0.102)$ & & & \\
\hline \multirow[t]{2}{*}{ Government96 } & & & & & & 0.0467 & & \\
\hline & & & & & & $(0.0821)$ & & \\
\hline \multirow[t]{2}{*}{ PoliticalParty $1_{02}$} & & & & & & & 0.254 & \\
\hline & & & & & & & $(0.191)$ & \\
\hline \multirow{2}{*}{ PoliticalParty2 } & & & & & & & & 0.00665 \\
\hline & & & & & & & & $(0.0839)$ \\
\hline \multirow[t]{2}{*}{ Constant } & $9.559^{* * *}$ & $9.781^{* * *}$ & $7.679^{* * *}$ & $8.064^{* * *}$ & $8.240^{* * *}$ & $6.569^{* * *}$ & $9.004^{* * *}$ & $6.881^{* * *}$ \\
\hline & $(2.543)$ & (2.559) & (2.082) & $(2.021)$ & (2.686) & $(1.819)$ & $(2.456)$ & $(1.777)$ \\
\hline Observations & 46 & 46 & 42 & 46 & 46 & 35 & 46 & 35 \\
\hline R-squared & 0.533 & 0.555 & 0.569 & 0.507 & 0.472 & 0.470 & 0.511 & 0.463 \\
\hline
\end{tabular}

Notes: The dependent variable is the average growth rate of real GDP per capita during 1997-2012.

Heteroskedasticity robust standard errors in parenthesis. Levels of significance: ${ }^{* * *} 1 \%,{ }^{* *} 5 \%, * 10 \%$.

\section{Results of cross-sectional analysis}

The OLS estimation results in Table I show that institutional trust is the most closely associated with growth. That is, all institutional trust measures (Justice, PropertyRights, \& LegalSystem) have significant positive effects while interpersonal 
trust and political trust do not. All other control variables have their expected signs. ${ }^{17)}$ The significance of both institutional trust and schooling suggests that institutional trust affects growth other than the schooling channel as measured in the secondary school enrollment rate. ${ }^{18)}$ Figure I visualizes the positive association between growth and institutional trust indices.

17) The expected sign of each coefficient based on growth theory and previous research (Barro, 1991, 1996; 2003; Barro \& Sala-i-Martin, 2004; Sala-i-Martin et al., 2004) is as follows: the coefficient of initial income is expected to have a negative (-) sign, reflecting the conditional convergence phenomenon. That is, after controlling for initial conditions, the low income country grows faster than the high income country. The relative price of investment should have a negative (-) sign. The school enrollment rate and trade openness are also expected to have positive $(+)$ signs. The government share of GDP, which reflects the size of the government, is expected to have a negative (-) sign because government intervention often causes market distortions or indebtedness problems. The last two variables are included in the model for robustness check.

18) Prior studies on interpersonal trust suggest that trust affects growth though the human capital channel. Therefore, two plausible explanations for the results are (i) institutional trust affects growth at least not through the human capital channel (if the secondary enrollment rate is a good measure for human capital), or (ii) the secondary enrollment rate is an imperfect measure for human capital. Results in Section VI indicate that (i) could be the case (see Table A11 in Appendix). 
Figure I : Institutional Trust and Growth: Partial Residual Plot for the baseline OLS model (Cross-section)
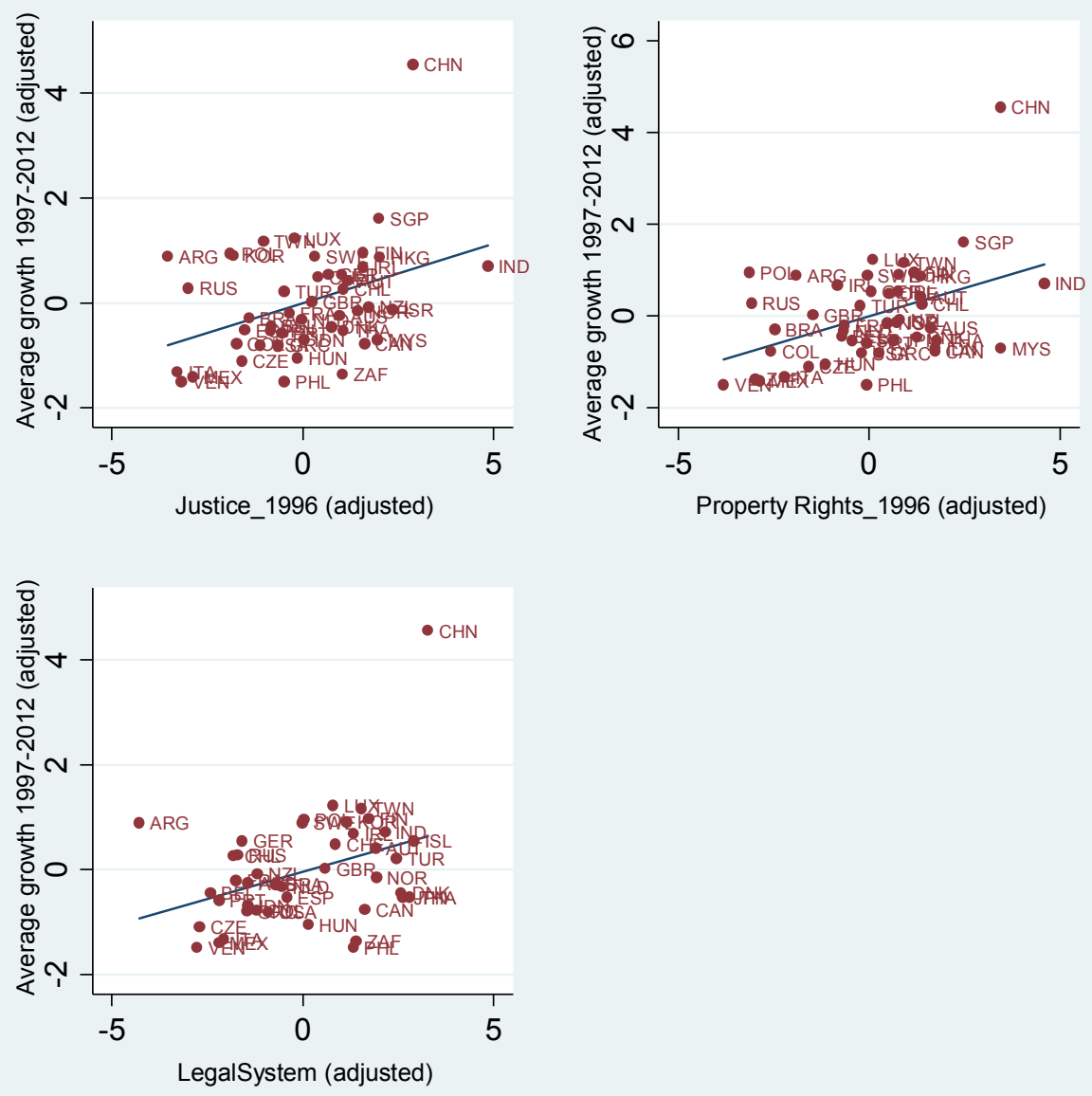

Notes: This figure illustrates the partial residual plot of the coefficients of trust indices for the baseline OLS model. Y-axis represents residuals $(\hat{e})$ from the equation, growth $=\beta_{0}+\beta_{1} \ln Y_{96}+\beta_{2} P_{-} i n v_{96}+\beta_{3} S_{\text {chool }}+e$. $\mathrm{X}$-axis represents residuals $(\hat{\varepsilon})$ from the equation, Institutional Trust $=\alpha_{0}+\alpha_{1} \ln Y_{96}+\alpha_{2} P_{-}$inv $v_{96}+$ $\alpha_{3}$ School $_{95}+\varepsilon$. The scatter plots show that institutional trust indices (Justice, PropertyRights, LegalSystem) are positively correlated with growth rate after controlling for the effects of initial income, the relative price of investments, and education. Although China appears to be an influential observation, the regression result (i.e., strong correlation between institutional trust and growth) does not change even when China is excluded from the sample. Quantile regression results also show that the results are not driven by outliers. 
Table II: Does institutional trust have an incremental explanatory power when interpersonal trust or the quality of institutions is also included as covariates? (OLS)

\begin{tabular}{|c|c|c|c|c|c|c|c|c|}
\hline & \multicolumn{4}{|c|}{$\begin{array}{l}\text { Interpersonal trust (MostPeople) } \\
\text { is controlled for }\end{array}$} & \multicolumn{4}{|c|}{$\begin{array}{c}\text { Quality of Institutions (PRS rule-of-law) } \\
\text { is controlled for }\end{array}$} \\
\hline & (1) & (2) & (3) & (4) & (5) & (6) & (7) & (8) \\
\hline $\ln Y_{96}$ & $\begin{array}{c}-0.722^{* *} \\
(0.292)\end{array}$ & $\begin{array}{c}-0.898^{* * *} \\
(0.311)\end{array}$ & $\begin{array}{c}-0.990^{* * *} \\
(0.336)\end{array}$ & $\begin{array}{c}-0.832^{* *} \\
(0.314)\end{array}$ & $\begin{array}{c}-0.995^{* *} \\
(0.468)\end{array}$ & $\begin{array}{c}-1.049^{* *} \\
(0.446)\end{array}$ & $\begin{array}{c}-1.093^{* *} \\
(0.446)\end{array}$ & $\begin{array}{c}-1.033^{* *} \\
(0.428)\end{array}$ \\
\hline P_inv96 & $\begin{array}{r}-0.0185^{* *} \\
(0.00864)\end{array}$ & $\begin{array}{l}-0.0192^{* *} \\
(0.00891)\end{array}$ & $\begin{array}{l}-0.0175^{*} \\
(0.00878)\end{array}$ & $\begin{array}{l}-0.0135 \\
(0.0127)\end{array}$ & $\begin{array}{l}-0.0108 \\
(0.00952)\end{array}$ & $\begin{array}{l}-0.0150 \\
(0.00908)\end{array}$ & $\begin{array}{l}-0.0143 \\
(0.00908)\end{array}$ & $\begin{array}{r}-0.00846 \\
(0.0122)\end{array}$ \\
\hline School95 & $\begin{array}{l}0.0215^{* *} \\
(0.00938)\end{array}$ & $\begin{array}{l}0.0218^{* *} \\
(0.00950)\end{array}$ & $\begin{array}{c}0.0275^{* *} \\
(0.0105)\end{array}$ & $\begin{array}{l}0.0283^{* *} \\
(0.0105)\end{array}$ & $\begin{array}{l}0.0218^{* *} \\
(0.00972)\end{array}$ & $\begin{array}{l}0.0225^{* *} \\
(0.00973)\end{array}$ & $\begin{array}{c}0.0291^{* * *} \\
(0.0104)\end{array}$ & $\begin{array}{l}0.0284^{* * *} \\
(0.00976)\end{array}$ \\
\hline MostPeople $_{96}$ & $\begin{array}{l}0.185 \\
(0.130)\end{array}$ & $\begin{array}{l}0.112 \\
(0.119)\end{array}$ & $\begin{array}{l}0.0900 \\
(0.118)\end{array}$ & $\begin{array}{l}0.126 \\
(0.131)\end{array}$ & & & & \\
\hline PRS rule-of-law96 & & & & & $\begin{array}{l}2.382 \\
(1.852)\end{array}$ & $\begin{array}{l}1.148 \\
(1.564)\end{array}$ & $\begin{array}{l}0.616 \\
(1.480)\end{array}$ & $\begin{array}{c}1.840 \\
(1.513)\end{array}$ \\
\hline [ Justice 96 & & $\begin{array}{l}0.182^{*} \\
(0.101)\end{array}$ & & & & $\begin{array}{l}0.199^{*} \\
(0.101)\end{array}$ & & \\
\hline PropertyRights96 & & & $0.209^{* *}$ & & & & $0.229^{* *}$ & \\
\hline & & & $(0.103)$ & & & & $(0.109)$ & \\
\hline LegalSystem 96 & & & & $\begin{array}{l}0.161 \\
(0.105)\end{array}$ & & & & $\begin{array}{l}0.192^{*} \\
(0.104)\end{array}$ \\
\hline Constant & $\begin{array}{l}8.064^{* * *} \\
(2.021)\end{array}$ & $\begin{array}{c}9.067^{* * *} \\
(2.140)\end{array}$ & $\begin{array}{c}9.357^{* * *} \\
(2.217)\end{array}$ & $\begin{array}{c}7.703^{* * *} \\
(2.070)\end{array}$ & $\begin{array}{c}8.796^{* * *} \\
(2.497)\end{array}$ & $\begin{array}{c}9.552^{* * *} \\
(2.494)\end{array}$ & $\begin{array}{c}9.758^{* * *} \\
(2.524)\end{array}$ & $\begin{array}{c}8.032^{* * *} \\
(2.207)\end{array}$ \\
\hline Observations & 46 & 46 & 46 & 42 & 46 & 46 & 46 & 42 \\
\hline R-squared & 0.507 & 0.549 & 0.565 & 0.587 & 0.489 & 0.540 & 0.557 & 0.589 \\
\hline
\end{tabular}

Notes: The dependent variable is the average growth rate of real GDP per capita during 1997-2012. Heteroskedasticity robust standard error in parentheses. Levels of significance: ${ }^{* * *} 1 \%, * * 5 \%, * 10 \%$. This table shows the estimations results when interpersonal trust (MostPeople) is controlled for (column 1-4) and when the quality of institutions (PRS rule-of-law) is controlled for (column (5)-(8)). The result shows that institutional trust indices (Justice, PropertyRights \& LegalSystem) maintain their explanatory power (columns (2)-(3), (6)-(8)) except for one case (columns (4)).

To examine whether institutional trust has an incremental explanatory power after controlling for interpersonal trust and the quality of institutions, the interpersonal trust measure (MostPeople) and the quality of institutions measure (PRS rule-of-law) are included as covariates. The Result in Table II shows that institutional trust is still significant, suggesting that institutional trust adds incremental explanatory power to growth even when interpersonal trust or the quality of institutions are included as covariates. One pattern to note in columns (5)-(8) is that, when institutional trust indices are included, the 
coefficient of the quality of institutions measure decreases substantially (e.g., $2.382 \rightarrow 0.616$ ), suggesting that institutions affect growth mostly through the channels of institutional trust.

Table III presents the results of the 2SLS approach. The first stage results show that hierarchical religions do discourage the formation of trust, which is consistent with the prior results of Zak and Knack (2001), Berggren and Jordahl (2006), and Bjørnskov (2007).19) The second stage results demonstrate the importance of institutional trust. Similar to the OLS results, two institutional trust indices (Justice, PropertyRights) are significant. The 2SLS estimators of the impacts of trust are bigger than those from the OLS, suggesting that a measurement error problem is more influential than the endogeneity problem in the OLS. As each trust index cannot capture all aspects of trust, the presence of measurement errors in the OLS estimators is not surprising. The coefficients of institutional trust $(0.352 \sim 0.358)$ show that the effect of trust is economically meaningful. If the coefficients are translated into a standardized coefficient, a one standard deviation change in institutional trust is associated with a change in $0.6 \sim 0.8$ standard deviation of growth, bigger than the standardized coefficient of the secondary school enrollment rate $(0.3 \sim 0.4)$. The magnitude of effects of trust is similar to the results in Knack and Keefer (1997), and Zak and Knack (2001), which report that a one standard deviation change in interpersonal trust is associated with a change in 0.6 standard deviation of growth.

19) These country-level results are different from those of the individual-level study by Alesina and Ferrara (2002), which reports that religious belief does not have a significant effect on trust. One plausible answer for the inconsistency between the country-level and the individual-level study is that what determines the level of trust could be a matter of whether the hierarchical culture is pervasive in the society as a whole (enough to interrupt social interaction), but not a matter of whether an individual has a hierarchical religion. See Alesina and Ferrara (2002, p. 220). 


\section{Table III: Trust and Growth: 2SLS Regressions (baseline)}

Panel A. First Stage Results- Hierarchical Religions and Trust

\begin{tabular}{|c|c|c|c|c|c|c|c|c|}
\hline Dep Var & $\begin{array}{c}\text { (1) } \\
\text { Justiceg6 }\end{array}$ & $\begin{array}{c}\text { (2) } \\
\text { Property } \\
\text { Rights96 }\end{array}$ & $\begin{array}{c}(3) \\
\text { Legal } \\
\text { Systemg6 }\end{array}$ & $\begin{array}{c}(4) \\
\text { Most } \\
\text { People } 96\end{array}$ & $\begin{array}{c}(5) \\
\text { Government } \\
\text { Policy } 96\end{array}$ & $\begin{array}{c}\text { (6) } \\
\text { Govermentos }\end{array}$ & $\begin{array}{c}(7) \\
\text { Political } \\
\text { Party } 1_{02}\end{array}$ & $\begin{array}{c}\text { (8) } \\
\text { Political } \\
\text { Party296 }\end{array}$ \\
\hline Hierarchical & $\begin{array}{c}-2.455^{* * *} \\
(0.680)\end{array}$ & $\begin{array}{c}-2.494^{* * *} \\
(0.660)\end{array}$ & $\begin{array}{c}-2.741^{* * *} \\
(0.769)\end{array}$ & $\begin{array}{c}-2.882^{* * *} \\
(0.635)\end{array}$ & $\begin{array}{l}-0.545 \\
(0.531)\end{array}$ & $\begin{array}{c}-2.009^{* *} \\
(0.830)\end{array}$ & $\begin{array}{r}-0.845 \\
(0.586)\end{array}$ & $\begin{array}{c}-2.814^{* * *} \\
(0.771)\end{array}$ \\
\hline $\begin{array}{l}\text { Other exogenous variable } \\
\text { in the 2nd stage }\end{array}$ & included & included & included & included & included & included & included & included \\
\hline Observations & 46 & 46 & 42 & 46 & 46 & 35 & 46 & 35 \\
\hline R-squared & 0.553 & 0.526 & 0.323 & 0.470 & 0.076 & 0.230 & 0.300 & 0.296 \\
\hline
\end{tabular}

Notes: Heteroskedasticity robust standard error in parentheses. Levels of significance: ${ }^{* * *} 1 \%, * * 5 \%$, * $10 \%$. a) Variables included: initial income level, relative price of investment, and schooling.

Panel B. Second Stage Results- Trust and Growth

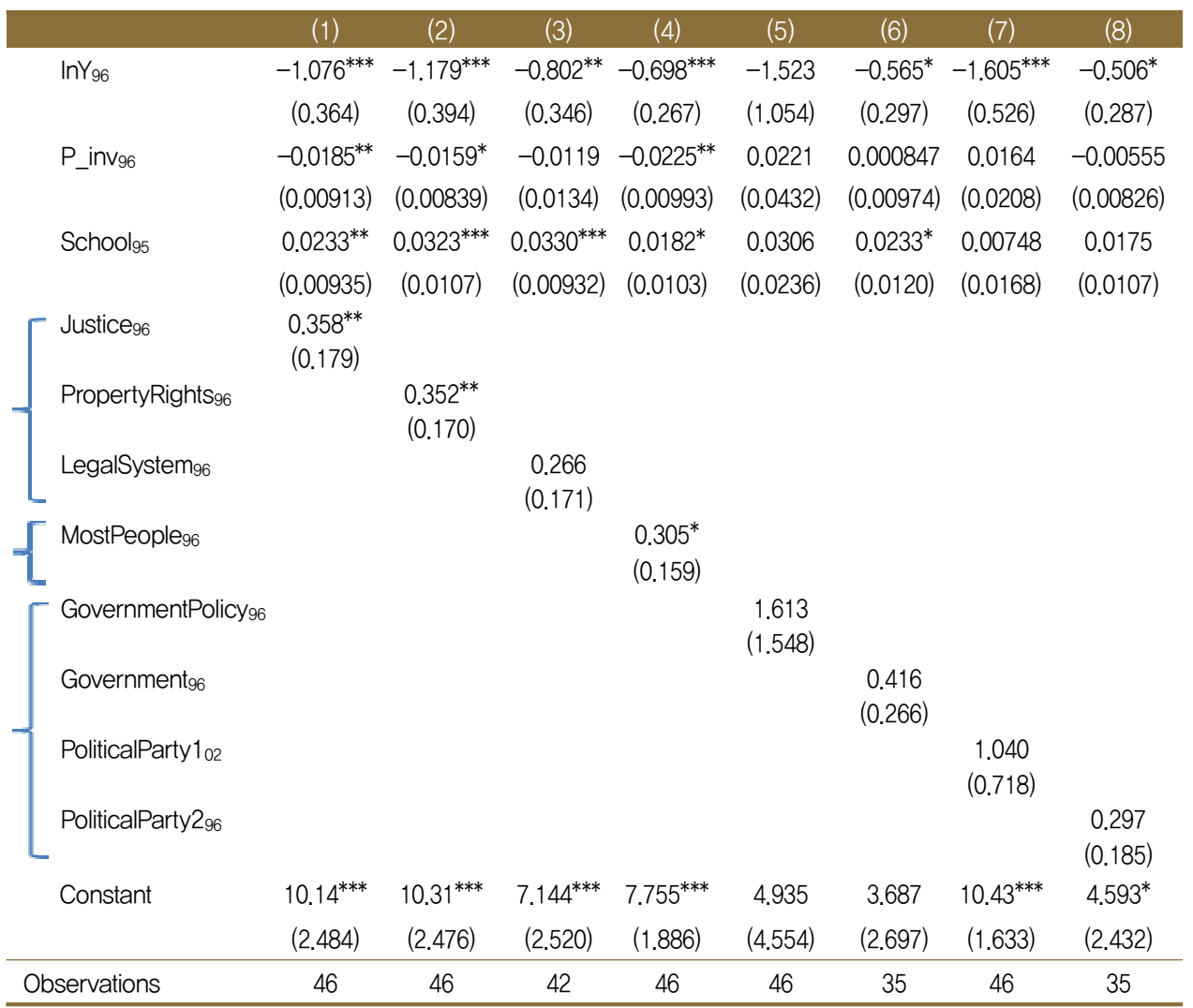

Notes: The dependent variable is the average growth rate of real GDP per capita during 1997-2012.

Heteroskedasticity robust standard error in parentheses. Levels of significance: ${ }^{* * *} 1 \%$, ** $5 \%, * 10 \%$. 


\section{Robustness checks}

To check the robustness, more regressions are estimated. First, regional dummies (East Asia and Nordic countries) and more covariates (government share of GDP and trade openness) are included in the model. Table A5 (Appendix) shows that the explanatory power of Justice and PropertyRights is weakened but still statistically significant, suggesting that the results are not driven by East Asia / Nordic exceptionalism (Delhey \& Newton, 2005) or two few control variables.

Second, to examine the effects of outliers, (i) I exclude China from the sample and (ii) employ median regression. Results in Appendix A6-A7 show that two institutional trust indices (Justice, PropertyRights) are still significant.

Third, to check if the different sample size (i.e., 46 vs. 42 vs. 35 countries depending on trust indices) is affecting the result significantly, the regression is estimated for 42 countries where most trust indices are available. The result in Table A8 (Appendix) is not different from the above results except that MostPeople and PoliticalParty1 are also significant.

Fourth, the schooling variable is excluded as an explanatory variable since it may capture most of the trust part of human capital. If trust affects growth both directly (e.g., through lowering transaction cost) and indirectly through human capital and if the secondary school enrollment rate is a unique, good proxy for human capital, then excluding schooling variables enables us to capture the sum of the direct and indirect effects of trust. Table A9 (Appendix) shows that Justice and PropertyRights are still significant. A similar magnitude of the coefficient of trust indices regardless of the omission of the schooling variable suggests that trust affects growth not through the channel of the secondary school enrollment rate.

For the 2SLS approach, regional dummies and more covariates are also included. Results in Table A9 (Appendix) shows that two institutional trust indices (PropertyRights, LegalSystem) are significant at the 5\% level. 


\section{Panel Data Analysis}

While the previous section uses "between variation" of trust in a cross-section of countries, this section utilizes "within variation" of trust in each country and examines a causal link from institutional trust to growth. Figure $\Pi$ illustrates how Justice (proxy for institutional trust) is different from the widely used PRS rule-of-law measure (proxy for the quality of institutions) in the selected two countries. Although both measures reflect institutional features of societies ( $\rho$ between Justice and PRS rule-of-law in a cross-section of 46 countries: $+0.659 * * *)^{20)}$, Justice shows a substantially larger time variation than PRS rule-of-law. This seems to be associated with the fact that Justice is based on pure survey results, capturing fluctuations in businessmen's subjective confidence. Although PRS rule-of-law also reflects subjective confidence (among country experts), the measure is subject to a peer-review process and barely changes without reasonable reasons. For example, media reports on scandals involving judges or prosecutors may lower public trust in institutions (Justice) substantially, but may have little impact on the quality of the legal system itself (PRS rule-of-law). Conversely, a reform of the legal system may improve the quality of institutions in the long-run, but public trust in the legal system may not change in the beginning of the reform. These examples suggest that institutional trust indices of this paper (Justice) may capture different aspects of institutions from the widely-used measure of institutions quality (PRS rule-of-law).

20) When the quality of institutions is proxied by the European mortality rate (Acemoglu et al., 2001), one can also find a similar relationship, a close association between the quality of institutions and institutional trust. In 16 countries, in which both the mortality rate and the IMD data are available, the correlation coefficient between Justice and the mortality rate is $-0.70^{* * *}$. The correlation coefficient between PropertyRights and the mortality rate is $-0.45^{*}$. 
Figure II : The Institutional Trust Index (Justice) vs. the Quality of Institutions Measure (PRS rule-of-law) for USA and Argentina

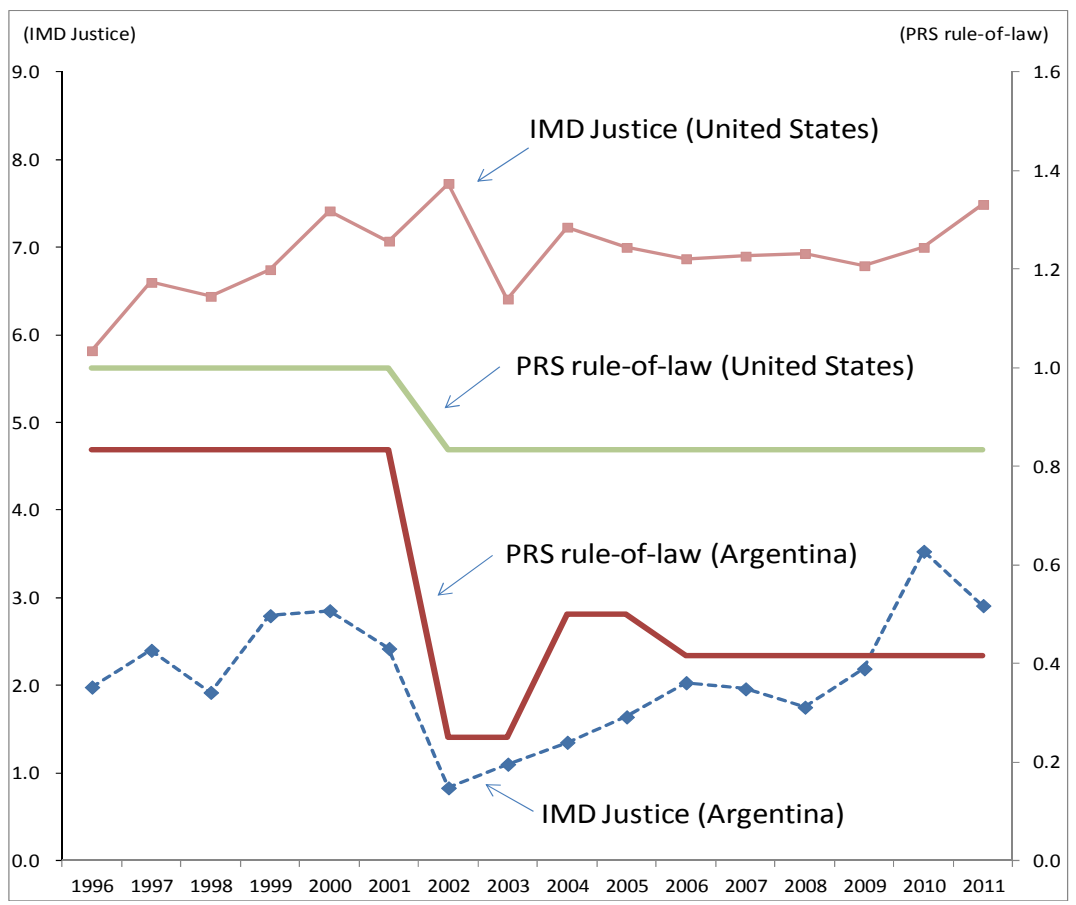

Notes: This figure compares the trend of the IMD trust index (Justice) with that of the quality of institutions measure (PRS rule-of-law) for selected two countries.

\section{Data and Estimation Strategy}

Panel data sets are constructed as follows (See Panel B of Table A3 for descriptive statics). Data are averaged over four-year non-overlapping periods between 1993 and 2012 to remove transitory fluctuations in growth.21) Therefore, we have five observations for 46 countries $(T=5, N=46)$. Unlike other data, the IMD survey on Justice and PropertyRights is available only from

21) Although using a five-year averaged data set is most widely used (Moral-Benito, 2012), this paper uses a four-year averaged data set to increase the number of observations in time dimension. Still, four-year averaging is enough to smooth the short-term fluctuations. 
1996 to 2011 when the data are retrieved. Hence, the case of the first observation of Justice and PropertyRights is based on the one-year (1996) survey results. The second, third, and fourth observations of institutional trust indices are based on four-year average figures. The fifth observation of the trust index is based on the three-year average (2009-2011). Data from WVS are not used because constructing panel data is not feasible due to the rolling sample design.

Arellano and Bond's (1991) difference GMM method is employed to resolve the endogeneity problem under the "small $\mathrm{T}$, large $\mathrm{N}$ " panel data structure. The basic form of a dynamic growth regression can be written as follows:

$$
y_{i, t}=\alpha y_{i, t-1}+\beta X_{i, t}+u_{i, t} \quad \text { where } u_{i, t}=\mu_{i}+\nu_{i, t}
$$

The dependent variable $\left(y_{i, t}\right)$ represents the growth rate. Variable $X_{i, t}$ represents the set of explanatory variables such as trust, the relative price of investment and time dummies. The term $\mu_{i}$ represents country-specific fixed effects. ${ }^{22}$ ) As the fixed effect term leads to the inconsistency of the OLS estimator ${ }^{23)}$, first differencing is conducted to eliminate the term.

$$
y_{i, t}-y_{i, t-1}=\alpha\left(y_{i, t-1}-y_{i, t-2}\right)+\beta\left(X_{i, t}-X_{i, t-1}\right)+\nu_{i, t}-\nu_{i, t-1}
$$

Equation (3), however, still has the endogeneity problem. The term, $y_{i, t-1}-y_{i, t-2}$, is correlated with the error term, $\nu_{i, t}-\nu_{i, t-1}$, because both terms are determined by $\nu_{i, t-1}$. If $X_{i, t}$ is endogenous, the term, $X_{i, t}-X_{i, t-1}$, also causes a similar problem ${ }^{24)}$. To resolve this, Anderson and Hsiao (1981),

22) Note that, although the initial level of GDP, which reflects the conditional convergence phenomenon (Barro, 2003), is not included as an explanatory variable in the panel model, the lagged dependent variable and the country fixed-effects term can replace the role of initial GDP. See also Moral-Benito (2012, pp. 576-577).

23) Note that $y_{i, t-1}$ is correlated with the error term $\left(u=\mu_{i}+\nu_{i, t}\right)$ due to the term, $\mu_{i}$. This leads to the inconsistency.

24) For example, suppose $X_{i, t}$ is trust. Then, $X_{i, t}$ can be determined by country-specific factors $\left(\mu_{i}\right)$ and contemporaneous economic shock $\left(\nu_{i, t}\right)$ because trust may have both the persistent features and the time-varying features. Hence, the term, $X_{i, t}-X_{i, t-1}$ also can be correlated with the error term $\nu_{i, t}-\nu_{i, t-1}$ due to the common term, $\nu_{i, t-1}$. 
and Arellano (1989) propose the instrumental variable (IV) approach which uses $y_{i, t-2}$ or $\Delta y_{i, t-2}$ as an instrument for $y_{i, t-1}-y_{i, t-2}$. (similarly, $X_{i, t-2}$ or $\Delta X_{i, t-2}$ as an instrument for $\left.X_{i, t}-X_{i, t-1}\right)$. Arellano and Bond (1991) propose the generalized version of the IV method. Its moment conditions are as follows:

$$
\begin{aligned}
& {\left[E\left[y_{i, t-p}\left(\nu_{i, t}-\nu_{i, t-1}\right)\right]=0\right], p=2,3, \cdots, T} \\
& {\left[E\left[X_{i, t-p}\left(\nu_{i, t}-\nu_{i, t-1}\right)\right]=0\right], p=2,3, \cdots, T}
\end{aligned}
$$

Consistency of this estimator depends crucially on the two assumptions, (i) no serial correlation in the error term $(\nu)$ and (ii) two moment conditions (4) \& (5) which imply that the realization of the past explanatory variable $\left(y_{i, t-p}\right.$ or $\left.X_{i, t-p}\right)$ is not correlated with the change in the error term $\left(\nu_{i, t}-\nu_{i, t-1}\right)$. If those conditions are met, the estimator can resolve the problem of endogeneity as well, while considering unobserved country-specific effects.

Control variables are selected among key determinants of growth reported in Moral-Benito (2012).25) He reports that the most robust determinants of growth in the panel data model are the relative price of investment; the remoteness proxied by the distance to world major cities; and the institutional framework proxied by the political rights index. The next robust determinants reported are the population size, trade openness, investment share, and the government consumption share of GDP. This paper will use those control variable sets. Some variables, however, are not used: the remoteness variable which does not have time variation is excluded as the model in this paper includes the country fixed effects term; the political rights index is not used as institutional aspects of the economy are proxied by institutional trust.

25) Note that Sala-i-Martin et al.'s (2004) study focuses on the determinants of growth only in a "cross-sectional" analysis. 


\section{Results of panel model}

Table IV reports the estimation results of Arellano and Bond's (1991) difference GMM method together with that of the fixed effect panel model. In applying the difference GMM method, only time dummies are assumed to be strictly exogenous. ${ }^{26)}$

Estimation results indicate that there is a causal relationship between institutional trust and growth. Columns (1) and (5) of the table present the estimation results for the fixed effect panel model. Although the results are exposed to the possible endogeneity problem, they reports that Justice it $_{\text {t }}$ and PropertyRights $_{i, t}$ are positively correlated with growth after controlling for country fixed effects and time dummies. Columns (2)-(4) and (6)-(8) report the one-step and two-step difference GMM estimator.27) Both estimators show that institutional trust $\left(\right.$ Justice $_{i, t}$, PropertyRights ${ }_{i, t}$ ) has a positive causal impact on economic growth after controlling for the endogeneity problem and the effects of various covariates. Interestingly and importantly, Justice ${ }_{i, t}$ and PropertyRights $s_{i, t}$ are significant even when the quality of institutions measure (PRS rule-of-law) is added (columns (1), (3), (5), (7)), suggesting that confidence or trust in institutions better captures the channel through which institutions affect economic activities, rather than the quality of institutions measure.

26) For example, when estimating column (2) in Table IV, lagged variables of growth, justice, $P$ _inv, pop are assumed to be predetermined but not strictly exogenous. Time dummy variables are assumed to be explicitly exogenous. STATA codes are as follows: "xtabond2 growth L.growth justice p_inv pop time*, gmm(L.(growth justice p_inv pop)) iv(time*) noleveleq small robust"

27) While the one-step estimator assumes homoskedastic standard errors, the two-step estimator uses the fi rst-step errors to construct heteroskedasticity-consistent standard errors. The one-step estimator is presented as a main result because the asymptotic standard errors of the two-step estimator tend to be downward biased (Bond, 2002). 
Table IV: Institutional Trust and Growth: (Dynamic) Panel Model

\begin{tabular}{|c|c|c|c|c|c|c|c|c|}
\hline \multirow[b]{3}{*}{ DepVar=Growth $h_{i, t}$} & \multirow{3}{*}{$\begin{array}{c}\text { Fixed } \\
\text { Effect } \\
\text { Model }\end{array}$} & \multicolumn{3}{|c|}{$\begin{array}{l}\text { Arellano-Bond } \\
\text { Difference GMM }\end{array}$} & \multirow{3}{*}{$\begin{array}{c}\text { Fixed } \\
\text { Effect } \\
\text { Model } \\
(5)\end{array}$} & \multicolumn{3}{|c|}{$\begin{array}{l}\text { Arellano-Bond } \\
\text { Difference GMM }\end{array}$} \\
\hline & & \multicolumn{2}{|c|}{ one-step estimator } & \multirow{2}{*}{$\begin{array}{c}\text { two- } \\
\text { step }\end{array}$} & & \multicolumn{2}{|c|}{ one-step estimator } & \multirow{2}{*}{$\begin{array}{c}\text { two- } \\
\text { step } \\
(8)\end{array}$} \\
\hline & & (2) & (3) & & & (6) & (7) & \\
\hline Justice $_{i, t}$ & $\begin{array}{c}0.864^{* * *} \\
(0.291)\end{array}$ & $\begin{array}{c}1.713^{* * * *} \\
(0.509)\end{array}$ & $\begin{array}{l}1.288^{* *} \\
(0.590)\end{array}$ & $\begin{array}{l}1.437^{* *} \\
(0.618)\end{array}$ & & & & \\
\hline PropertyRights $_{i, t}$ & & & & & $\begin{array}{c}0.829^{* * *} \\
(0.253)\end{array}$ & $\begin{array}{c}1.740^{* * *} \\
(0.568)\end{array}$ & $\begin{array}{c}0.868 \\
(0.581)\end{array}$ & $\begin{array}{c}1.479^{* * *} \\
(0.467)\end{array}$ \\
\hline PRS-rule-of-lawi,t & $\begin{array}{l}-2.303 \\
(1.764)\end{array}$ & & $\begin{array}{c}3.566 \\
(4.057)\end{array}$ & & $\begin{array}{c}-3.070^{*} \\
(1.785)\end{array}$ & & $\begin{array}{c}3.923 \\
(4.766)\end{array}$ & \\
\hline$P_{-} i n v_{i, t}$ & $\begin{array}{c}-0.00689 \\
(0.0149)\end{array}$ & $\begin{array}{l}0.00799 \\
(0.0433)\end{array}$ & $\begin{array}{c}-0.0612^{*} \\
(0.0346)\end{array}$ & $\begin{array}{l}-0.0315 \\
(0.0394)\end{array}$ & $\begin{array}{l}-0.0218 \\
(0.0157)\end{array}$ & $\begin{array}{l}-0.0106 \\
(0.0505)\end{array}$ & $\begin{array}{c}-0.0823^{* *} \\
(0.0332)\end{array}$ & $\begin{array}{c}-0.0776^{*} \\
(0.0427)\end{array}$ \\
\hline$p_{o p}, t$ & $\begin{array}{l}0.0231^{* * *} \\
(0.00874)\end{array}$ & $\begin{array}{c}0.0423^{* *} \\
(0.0171)\end{array}$ & $\begin{array}{c}0.0306 \\
(0.0190)\end{array}$ & $\begin{array}{l}0.0390^{* *} \\
(0.0168)\end{array}$ & $\begin{array}{l}0.0225^{* * *} \\
(0.00864)\end{array}$ & $\begin{array}{c}0.0434^{* *} \\
(0.0183)\end{array}$ & $\begin{array}{c}0.0276 \\
(0.0172)\end{array}$ & $\begin{array}{l}0.0335^{* *} \\
(0.0134)\end{array}$ \\
\hline Growth $_{i, t-1}$ & & $\begin{array}{l}0.0127 \\
(0.155)\end{array}$ & $\begin{array}{c}-0.000114 \\
(0.151)\end{array}$ & $\begin{array}{l}0.0104 \\
(0.136)\end{array}$ & & $\begin{array}{l}0.0508 \\
(0.163)\end{array}$ & $\begin{array}{l}0.0337 \\
(0.141)\end{array}$ & $\begin{array}{l}0.0671 \\
(0.189)\end{array}$ \\
\hline Share_Invi,t & & & $\begin{array}{c}0.123 \\
(0.107)\end{array}$ & $\begin{array}{l}0.0193 \\
(0.123)\end{array}$ & & & $\begin{array}{c}0.142 \\
(0.102)\end{array}$ & $\begin{array}{l}0.0915 \\
(0.118)\end{array}$ \\
\hline Share_Govit, & & & $\begin{array}{c}0.134 \\
(0.425)\end{array}$ & $\begin{array}{c}0.384 \\
(0.539)\end{array}$ & & & $\begin{array}{c}0.295 \\
(0.418)\end{array}$ & $\begin{array}{l}0.908^{*} \\
(0.534)\end{array}$ \\
\hline Openness $_{i, t}$ & & & $\begin{array}{l}0.00370 \\
(0.0265)\end{array}$ & $\begin{array}{c}0.0106 \\
(0.0347)\end{array}$ & & & $\begin{array}{l}0.00646 \\
(0.0252)\end{array}$ & $\begin{array}{l}0.00886 \\
(0.0246)\end{array}$ \\
\hline Constant & $\begin{array}{c}-4.347^{*} \\
(2.555)\end{array}$ & & & & $\begin{array}{l}-2.947 \\
(2.192)\end{array}$ & & & \\
\hline Country Fixed Effects & YES & YES $^{c}$ & $\mathrm{YES}^{\mathrm{C}}$ & YES $^{c}$ & YES & YES $^{c}$ & YES $^{c}$ & YES $^{c}$ \\
\hline Time dummies & YES & YES & YES & YES & YES & YES & YES & YES \\
\hline serrial correlation te & $t(p-\text { value })^{a}$ & 0.411 & 0.085 & 0.243 & & 0.238 & 0.049 & 0.143 \\
\hline Hansen over ID tes & $(p-\text { value })^{b}$ & 0.503 & 0.464 & 0.426 & & 0.198 & 0.677 & 0.463 \\
\hline Countries (N) & 46 & 46 & 46 & 46 & 46 & 46 & 46 & 46 \\
\hline Observations (NxT) & 230 & 138 & 138 & 138 & 230 & 138 & 138 & 138 \\
\hline
\end{tabular}

Notes: Heteroskedasticity and country-specific autocorrelation consistent t-statistics are in parentheses. Time dummies and fixed effect terms are not reported. Levels of significance: ${ }^{* * *} 1 \%,{ }^{* *} 5 \%, * 10 \%$. Estimation model is equation (3): $y_{i, t}-y_{i, t-1}=\alpha\left(y_{i, t-1}-y_{i, t-2}\right)+\beta\left(X_{i, t}-X_{i, t-1}\right)+\nu_{i, t}-\nu_{i, t-1}$, which is equivalent to equation (2).

The dependent variable is the 4-year average of the real per capita GDP growth rate during 1993 2012. All explanatory variables are also based on the 4-year average figure for the same period whenever data are available. Hence, the panel data has 230 observations $(T=5, N=46)$. Note that when the GMM method is applied, the number of observations decreases because yt-2, and Xt-2 are used as instruments. In the difference GMM estimation, all explanatory variables except for time dummies are assumed to be endogenous and hence instrumented by instrumental variables. Time dummies are assumed to be strictly exogenous, which is a standard assumption in the dynamic panel model.

a) The null hypothesis is that the first-differenced errors exhibit no second-order serial correlation. For example, the result in column (2) says that one cannot reject the null hypothesis of no second-order serial correlation as the $p$-value is 0.411 .

b) The null hypothesis is that instruments are not correlated with the error term $\left(\nu_{i, t}\right)$. For example, the result in column (2) says that one cannot reject the null hypothesis that orthogonality conditions are valid as the $p$-value is 0.503 .

c) As this paper estimates the first differenced equation, country fixed effects cancel out. 
Results of serial correlation tests for the presence of second order autocorrelation and the Hansen test on the over-identification restriction indicate that the assumptions of Arellano and Bond's model are met in most cases. This implies that (i) residuals of growth $\left(\nu_{i, t}\right)$ are not correlated with those two-periods (or 8 years) before $\left(\nu_{i, t-2}\right)$; and (ii) trust and the growth rate of two-periods before $\left(X_{i, t-2}, y_{i, t-2}\right)$ are not correlated with the change in residuals of growth $\left(\nu_{i, t}-\nu_{i, t-1}\right)$. If there is any connection, trust and the growth rate of 8 years before $\left(X_{i, t-2}, y_{i, t-2}\right)$ affect current growth only through the difference in current trust $\left(X_{i, t}-X_{i, t-1}\right)$ and the difference in the past growth rate $\left.\left(y_{i, t-1}-y_{i, t-2}\right) .28\right)$ This allows us to identify how the exogenous variation in trust affects growth. It is worthwhile to note that the Hansen test on the over-identification restriction provides reliable information since only time dummies are assumed to be strictly exogenous, and hence, the results are not confounded by dubious instruments. ${ }^{29)}$ In the case of result (3) and result (7), however, the second order autocorrelation problem seems to be present. The coefficients of the difference GMM estimator for Justice and PropertyRights are estimated to be bigger than those of the fixed effect model, indicating the presence of measurement error in institutional trust in the fixed effect model.30)

28) As $X_{i t}$ is a set of explanatory variables, it includes other explanatory variables such as the relative price of investment and the population as well as trust indices. In the explanation, I assumed $X_{i t}$ is trust for simplicity.

29) Intuitively, what the Hansen test does is to compare the results from different instrumental variable sets in order to see if they are systematically different from each other. If they are different, it implies that one or more instruments are invalid. Note that the Hansen test is based on the assumption that at least one instrument is valid.

30) This paper does not employ the system GMM estimator (Arellano \& Bover, 1995; Blundell \& Bond, 1998) in this section, because (i) the additional moment condition for the system GMM could be too restrictive for the growth panel model and (ii) it is unlikely that the difference GMM estimator has the problem of weak instruments that Blundell and Bond (1998) point out, since the coefficient of the lagged dependent variable is small (hence, it is far from a random walk process). The reason for (i) is as follows. Suppose the data generating process is as follows: $y_{i, t}=\alpha y_{i, t-1}+\mu_{i}+\nu_{i, t}$. To apply the system GMM, initial deviations $\left(\nu_{i, 1}\right)$ from the stationary level $\left(\mu_{i} /(1-\alpha)\right)$ should be uncorrelated with the level of the stationary state $\left(\mu_{i} /(1-\alpha)\right.$ ) (Blundell \& Bond 1998, p. 124). This implies "faster-growing individuals [countries] are not systematically closer to or farther from their steady states than slower-growing ones" (Roodman 2009, p. 30). However it is highly likely that faster-growing low-income countries are farther from their steady states than slower-growing advanced economies (Barro \& Sala-i-Martin, 1992). Thus, the additional moment condition for the system GMM might not hold in the growth panel model. 


\section{Interpretation and Discussion}

\section{Trust in Institutions vs. Trust in People}

The results of cross-section and panel data analysis indicate that trust in institutions is important in economic activities. Although most of the existing papers on trust focus on interpersonal trust, a great amount of literature on institutions has stressed the importance of formal institutions. ${ }^{31)}$ Penalties or incentives from formal institutions can more directly affect the utility of economic agents than those from informal sanctions such as moral norms, which are often associated with interpersonal trust. For example, the disutility from imprisonment can be larger than that from criticism of others. Hence, when information about the type of another player is not given (whether he/she is reliable or not), it is reasonable to infer the future actions of that player based on the incentive structure of the game (e.g., penalties for cheating).

The high correlation between institutional trust and a law-abiding behavior supports the above argument. The data on a law-abiding behavior are obtained from a Reader's Digest's (2001) field experiment, in which cash bearing wallets are dropped in streets in 33 countries and "the return rate of the wallets" is reported. Scatter plots and correlation coefficients in Figure III show that Justice and PropertyRights have a higher correlation $(\rho=0.64 \sim 0.58)$ than interpersonal trust $(\rho=0.55)$. This suggests that a better predictor for the actual behavior of others could be the expectations derived from the formal incentive structure of the society. In the language of Knack (2001), the result suggests that an enforcement mechanism implemented by the third party (e.g., the penal system) could be more important than that implemented by the first party (e.g., ethical or moral codes) or by the second party (e.g., repeated relationships).

31) Fisman and Miguel (2007) provide micro evidence of how legal enforcement affects economic agents' decisions over social norms. An experimental study by Bohnet and Baytelman (2007) shows how institutions, which are measured by the penalty of betrayal in an investment game, change subjects' expectations of the trustworthiness of others. On the other hand, studies by Besley (1995), and Johnson, McMillan and Woodruff (2002) show how the legal protection of property rights affects investment decisions. 
Figure III: Scatter Plots between the Return Rate of Lost Wallets \& Trust Indices
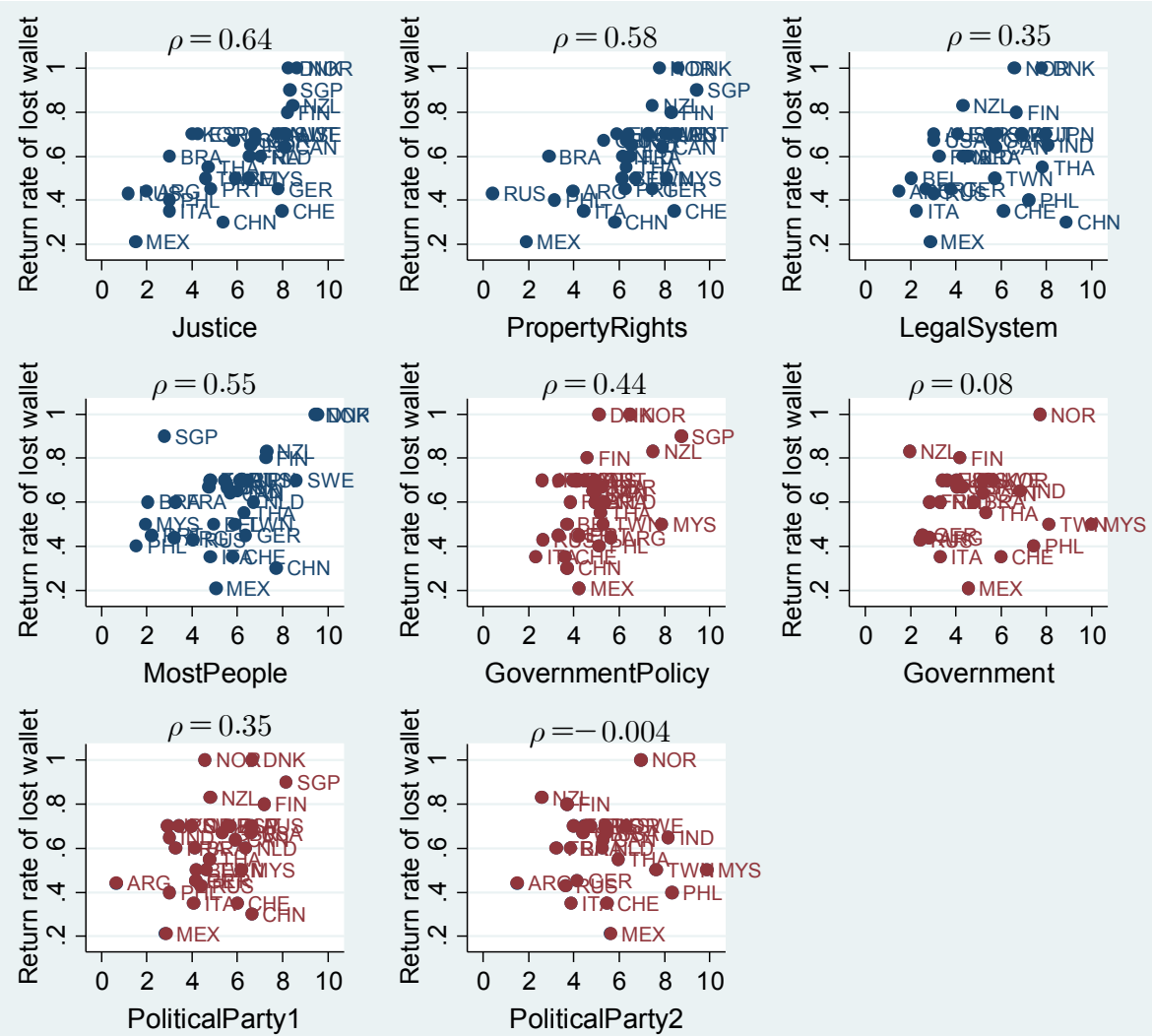

Notes: Figures show scatter plots when sample countries are set to 24 countries in which all data (the return rate of lost wallets, trust indices) are available. Two institutional trust indices (Justice, PropertyRights) show the strongest correlation with the return rate.

The finding that institutional trust is more closely associated with trust in "unknown person" provides additional grounds why institutional trust is important in a trade relationship. That is, as the trade with unknown people involves high monitoring costs and insurance costs, trust in those people is critical to reduce transaction costs. To examine if institutional trust is more closely associated with trust in "unknown people" than trust in "acquaintances," 
the radius reported in Delhey, Newton and Welzel (2011) is utilized. The radius approaches zero if respondents of the country imagine friends or family when responding to the most people question. It approaches one if respondents imagine the general public. The "Radius-adjusted-MostPeople" is calculated by multiplying the radius and MostPeople, so that the index captures generalized trust. In a cross-section of 29 countries in which all related indices are available, Spearman's rank correlation coefficient between Justice and MostPople is 0.539, and the coefficient between Justice and Radius-adjusted-MostPeople is 0.603 . Similarly, Spearman's rank correlation coefficient between PropertyRights and MostPople is 0.484 while the coefficient between PropertyRights and Radius-adjusted-MostPeople is 0.509 . These results suggest that institutional trust is closely related to trust in "anonymous" trade partners.

The non-robustness of political trust in explaining growth is not surprising considering that political trust is often related to the degree of interest in politics and pride in the national political system (Newton, 2001, p. 204), which is not directly associated with economic activities.

\section{Further Analysis and Discussions on Institutional Trust}

\section{How institutional trust affects growth?: investment channel vs. schooling channel}

To explore the channels through which institutional trust affects growth, more cross-sectional regressions are estimated. Two possible channels, the investment channel and the schooling channel are examined. ${ }^{32)}$

Estimation results of OLS in Table A11 (Appendix) provide suggestive evidence that institutional trust affects growth through the investment channel, but not through the schooling channel. That is, institutional trust indices in 1996 (Justice, PropertyRights and LegalSystem) are strongly correlated with the average investment/GDP ratio during 1997-2010, but not with the secondary school enrollment rate or average years of schooling. The valid investment channel is consistent with Knack and Keefer (1997) and in line with the

32) Among the three channels which are discussed in the Section II (i.e. the investment, human capital, and governance channels), the governance channel is not considered due to the measurement problem. 
transaction cost argument. But the insignificant schooling channel of institutional trust contrasts with the study on interpersonal trust such as Bjørnskov (2009, 2012), and Dearmon and Grier (2011), which report interpersonal trust affects growth through schooling or human capital channel.

\section{Where does institutional trust come from? How does it evolve?}

While previous literatures (Zak \& Knack, 2001; Alesina \& Ferrara, 2002; Bjørnskov, 2007) only focus on the determinants of interpersonal trust, this paper explores the determinants of institutional trust. As possible explanatory variables for institutional trust, the quality of institutions is considered as well as other standard explanatory variables for interpersonal trust, such as the fraction of hierarchical religions, the heterogeneity in income and race, and the level of income and education.

Cross-sectional regression results in Table A12 (Appendix) suggest that institutional trust is associated with two primary factors: an "institutional factor" that is specific to institutional trust; and "common factors," such as the income level and hierarchical religions, which also affect interpersonal trust. That is, the result shows that the quality of institutions (PRS rule-of-law, + ), the income level $(+)$ and hierarchical religions (-) are good predictors of institutional trust. ${ }^{33)}$ The effects of income inequality, schooling and ethnic diversity on institutional trust are not significant in the 46 countries. In the case of interpersonal trust, it is only explained by common factors (hierarchical religions and income inequality), not by institutional factors. ${ }^{34)}$

33) The magnitude of the coefficients indicates that the effect of the quality of institutions on institutional trust is substantial. The results in columns (1)-(2) in Table A12 show that a one point increase in the quality of institutions (PRS rule-of law) leads to 3.513 and 6.044 increase in Justice and PropertyRights. For example, the low level of the quality of institutions in Venezuela, which is 0.21 point lower that the average of 46 countries, explains about $0.75 \sim 1.29(-0.21 \times 3.513,-0.21 \times 6.044)$ loss in Justice and PropertyRights. This effect is bigger than that of hierarchical religions. The high fraction of hierarchical religions in Venezuela, which is $0.46 \%$ point higher than the average of 46 countries, can explain $0.61 \sim 1.06(0.46 \mathrm{x}-2.280,0.46 \mathrm{x}$ -1.337) loss in Justice and PropertyRights.

34) Note that Zak and Knack (2001) report that hierarchical religions (-), the quality of institutions (+), the initial GDP level $(+)$, income inequality (-), schooling (weak positive effects) and ethnic homogeneity (quadratic) are important determinants of interpersonal trust in a cross-section of countries. Hence, overall, their results are similar to those in this paper although the level of significance is different. 
The panel data analysis is also utilized in order to investigate what explains "time variation" of institutional trust. Study on the time variation of trust is particularly important because policy makers' main interests are "what can we do given the restrictions of time-invariant factors?" Specifically, a dynamic panel model is employed to consider the dynamic nature of the evolution of trust.

The result in Table A13, which is based on a 4-year non-overlapping average data set for the period of 1993-2012, shows that the quality of institutions is an important determinant of institutional trust along with other factors such as current economic situations and income inequality. ${ }^{35)}$ It implies that enhancing institutional trust may be possible by maintaining good institutions and business conditions, and by lowering income inequality. The causal relationship between institutions and institutional trust demonstrates that "collective learning" (Mantzavinos, North, \& Shariq, 2004, p. 77) on institutions is occurring. Large coefficients of the lagged dependent variable $(0.70 \sim 0.80)$ in columns (5)-(8) indicate that such learning effect is persistent over time. This can explain why institutional outcomes have long-lasting effects as presented in Acemoglu and Robinson (2001, 2012).

All in all, the result in Table A13, showing both agents' updating process based on present institutions and the persistency of updated beliefs, is consistent with the literature on the intergenerational transmission of values and beliefs (Tabellini 2008; Guiso et al., 2008b; Alesina \& Giuliano, 2013). ${ }^{36)}$

35) For example, the result in column (7) indicates that one point increase in the PRS rule-of-law index raises Justice by 2.021point in the short-run and 7.77point $(2.021 /(1-0.740))$ in the long-run.

36) Alesina and Giuliano (2013) provide excellent reviews on this topic, the interaction of cultrue and institutions. 


\section{Conclusion}

Throughout this paper, it has been argued that there is a continuum of definitions for the concept of trust, and the most people question might capture only a narrow concept of trust. Survey results of the IMD and the WVS are classified into three types of trust: interpersonal trust, institutional trust and political trust. In a cross-sectional analysis, the explanatory power of three types of trust regarding growth is examined. During the course of the analysis, this paper pays attention to the model uncertainty in growth regression and the possibility of reverse causality and endogeneity. The robustness of the result is also checked by considering regional dummies, more covariates and different specifications. The empirical evidence from a cross-section of 46 countries is that institutional trust (e.g. justice, protection of property rights) is robustly related to growth. In particular, institutional trust is estimated to have a stronger impact on growth than the schooling variable. The result of Arellano and Bond's difference GMM model indicates a strong causal link from institutional trust to growth.

On the determinants of institutional trust, this paper finds two primary factors in a cross-sectional dimension: an "institutional factor" that is specific to institutional trust (the quality of institutions); and "common factors" that affect all types of trust (hierarchical religions and the income level). In a time dimension, institutional trust is determined by the quality of institutions, income inequality and business conditions when time-invariant factors are controlled for.

The estimation results imply that trust in the social system or trust in the rule of the game is important. That is, the result suggests that the perception or evaluation of the "incentive structure facing ones' trade partner" (Zak \& Knack 2001, p. 303), which is based on formal institutions, could have a critical role in laying the foundation for economic activities. This paper documents two facts that are consistent with the argument: (i) institutional trust is a better predictor than interpersonal trust for the "actual behavior" of citizens as measured by the return rate of lost wallets; and (ii) institutional trust is closely associated with 
trust in "unknown" people as measured by radius-adjusted interpersonal trust. Hence, institutional trust is a key factor reducing transaction costs which are high in the trade with unknown partners. A strong association between institutional trust and investment/GDP ratio presented in Section VI supports the transaction cost argument.

The second implication of this paper is that a trust-enhancing policy can be meaningful. Bjørnskov (2007) concludes that interpersonal trust (or so called generalized trust) is a fairly "stable cultural feature" of society, and hence, creating trust is almost impossible. However, this paper shows that enhancing trust may be possible by maintaining good institutions and lowering income inequality ${ }^{37)}$ if the definition of trust is widened to include institutional trust. One of the trust indices, Justice, provides a good example. Trust in justice can be fostered by maintaining a fair and just penal system.

Lastly, it should be acknowledged again that this paper uses the data from two different survey sources. Hence, the result should be interpreted as indicating that a certain type of trust (institutional trust) also plays an important role in economic activities, rather than suggesting that other types of trust are not relevant or not important. In addition, this study covers only 46 countries in which the IMD survey is conducted. Thus, the sample has more open and more developed countries. This might be one of the reasons behind the weak explanatory power of interpersonal trust in those 46 countries as opposed to the previous studies on interpersonal trust.

A remaining question is how different types of trust interact with one another. Although the existing time-series of trust data is short, it will help identify the interaction as IMD and WVS data accumulate. This will allow us to examine how culture and institutions interact with each other in the dimension of trust.

37) This paper does not deny that trust has deep-rooted or stable features. Rather, this paper uses the persistent aspect of trust (Guiso, Sapienza, \& Zingales, 2009) in applying the instrumental variable approach in a cross-sectional analysis (note that Tabellini (2008), Guiso et al. (2008b), and Ljunge (2014) show how values and beliefs are transmitted across generations). The emphasis here is that economic agents update their beliefs based on current institutions (See Section VI.2). 


\section{References}

Acemoglu, D., \& Robinson, A. (2001), "The Colonial Origins of Comparative Development: An Empirical Investigation," The American Economic Review, Vol. 91(5), pp. 1369-1401.

Acemoglu, D., Johnson, S., \& Robinson, J. A. (2002), "Reversal of Fortune: Geography and Institutions in the Making of the Modern World Income Distribution," The Quarterly Journal of Economics, Vol. 117(4), pp. 1231-1294.

Acemoglu, D., Johnson, S., \& Robinson, J. A. (2005), "Institutions as a Fundamental Cause of Long-run Growth," Handbook of Economic Growth, Vol. 1, pp. 385-472.

Acemoglu, D., \& Robinson, J. A. (2012), Why Nations Fail: Origins of Power, Poverty and Prosperity, Crown Publishers (Random House), March 2012.

Alesina, A., Devleeschauwer, A., Easterly, W., Kurlat, S., \& Wacziarg, R. (2003), "Fractionalization," Journal of Economic Growth, Vol. 8(2), pp. 155-194.

Alesina, A., \& Giuliano, P. (2013), "Culture and Institutions," NBER Working Papers No. 19750.

Alesina, A., \& La Ferrara, E. (2002), "Who Trusts Others?," Journal of Public Economics, Vol. 85(2), pp. 207-234.

Algan, Y., \& Cahuc, P. (2010), "Inherited Trust and Growth," The American Economic Review, pp. 2060-2092.

Anderson, T. W. and Hsiao, C. (1981), "Estimation of Dynamic Models with Error Components," Journal of the American Statistical Association, Vol. 76, pp. 598-606.

Arellano, M. (1989), "A Note on the Anderson-Hsiao Estimator for Panel Data," Economics Letters, Vol. 31(4), pp. 337-341.

Arellano, M., \& Bond, S. (1991), "Some Tests of Specification for Panel Data: 
Monte Carlo Evidence and an Application to Employment Equations," The Review of Economic Studies, Vol. 58(2), pp. 277-297.

Arellano, M., \& Bover, O. (1995), "Another Look at the Instrumental Variable Estimation of Error-components Models," Journal of Econometrics, Vol. 68(1), pp. 29-51.

Barro, R. J. (1991), "Economic Growth in a Cross-Section of Countries," Quarterly Journal of Economics, Vol. 106, pp. 407-443.

Barro, R. J. (1996), "Determinants of Economic Growth: a Cross-country Empirical Study" NBER Working Papers No. 5698.

Barro, R. J. (2003), "Determinants of Economic Growth in a Panel of Countries," Annals of Economics and Finance, Society for AEF, Vol. 4(2), pp. 231-274.

Barro, R. J., \& Lee J., (2010), "A New Data Set of Educational Attainment in the World, 1950-2010," Journal of Development Economics, Vol. 104, pp. 184-198.

Barro, R. J., \& McCleary, R. (2003), "Religion and Economic Growth," NBER Working Papers No. 9682.

Barro, R. J., \& Sala-i-Martin, X. (1992), “Convergence," Journal of Political Economy, Vol. 100, pp. 223-251.

Barro, R. J., \& Sala-i-Martin, X. (2004), Economic Growth, MIT Press. Cambridge, Massachusettes.

Becker, S., Wößssmann, L., (2009), "Was Weber Wrong? A Human Capital Theory of the Protestant Economic History," Quarterly Journal of Economics, Vol. 124, pp. $531-596$

Bellemare, C., \& Kröger, S. (2007), "On Representative Social Capital," European Economic Review, Vol. 51(1), pp. 183-202.

Berggren, N., and Jordahl, H. (2006), "Free to Trust? Economic Freedom and Social Capital,” Kyklos, Vol. 59, pp. 41-69. 
Besley, T. (1995), "Property Rights and Investment Incentives: Theory and Evidence from Ghana," Journal of Political Economy, pp. 903-937.

Bjørnskov, C. (2007), "Determinants of Generalized Trust: A Cross-country Comparison," Public Choice, Vol. 130, pp. 1-21.

Bjørnskov, C. (2009), "Social Trust and the Growth of Schooling," Economics of Education Review, Vol. 28, pp. 249-257.

Bjørnskov, C. (2012), "How Does Social Trust Affect Economic Growth?," Southern Economic Journal, Vol. 78(4), pp. 1346-1368.

Bjørnskov, C., \& Méon, P. G. (2013), "Is Trust the Missing Root of Institutions, Education, and Development?," Public Choice, Vol. 157(3-4), pp. 641-669.

Blundell, R., \& Bond, S. (1998), "Initial Conditions and Moment Restrictions in Dynamic Panel Data Models," Journal of Econometrics, Vol. 87(1), pp. 115-143.

Bohnet, I., \& Huck, S. (2004), "Repetition and Reputation: Implications for Trust and Trustworthiness When Institutions Change," American Economic Review, pp. 362-366.

Bohnet, I., \& Baytelman, Y. (2007), "Institutions and Trust Implications for Preferences, Beliefs and Behavior," Rationality and Society, Vol. 19(1), pp. 99-135.

Bond, S. R. (2002), "Dynamic Panel Data Models: A Guide to Micro Data Methods and Practice," Portuguese Economic Journal, Vol. 1(2), pp. 141-162.

Cavalcanti, T. V., Parente, S. L., \& Zhao, R. (2007), "Religion in Macroeconomics: A Quantitative Analysis of Weber's Thesis," Economic Theory, Vol. 32(1), pp. 105-123.

Das, T. K., \& Teng, B. S. (2001), “Trust, Control, and Risk in Strategic Alliances: An Integrated Framework," Organization Studies, Vol. 22(2), pp. 251-283

Dearmon J., Grier, R,. (2011), "Trust and the Accumulation of Physical and 
Human Capital," European Journal of Political Economy, Vol. 27, pp. 507-519.

Delhey, J., \& Newton, K. (2003), "Who Trusts?: The Origins of Social Trust in Seven Societies," European Societies, Vol. 5(2), pp. 93-137.

Delhey, J., \& Newton, K. (2005), "Predicting Cross-national Levels of Social Trust: Global Pattern or Nordic Exceptionalism?," European Sociological Review, Vol. 21, pp. 311-327.

Delhey, J., Newton, K., \& Welzel, C. (2011), "How General is Trust in "most people"? Solving the radius of trust problem,“ American Sociological Review, Vol. 76(5), pp. 786-807.

Dincer, O. C., \& Uslaner, E. M. (2010), "Trust and Growth," Public Choice, Vol. 142(1-2), pp. 59-67.

Durlauf, S., P. Johnson, and J. Temple (2005), "Growth Econometrics," in Aghion, P., Durlauf, S. (eds.), Handbook of Economic Growth, Amsterdam, North-Holland.

Durlauf, S. N., Kourtellos, A., \& Tan, C. M. (2012), "Is God in the Details? A Reexamination of the Role of Religion in Economic Growth," Journal of Applied Econometrics, Vol. 27(7), pp. 1059-1075.

Fisman, R., \& Miguel, E. (2007), "Corruption, Norms, and Legal Enforcement: Evidence from Diplomatic Parking Tickets," Journal of Political Economy, Vol. 115(6), pp. 1020-1048.

Gambetta, Diego (2000), 'Can We Trust Trust?', in Gambetta, Diego (ed.) Trust: Making and Breaking Cooperative Relations, electronic edition, Department of Sociology, University of Oxford, chapter 13, pp. 213-237

Glaeser, E., Laibson, D., Scheinkman J., and Soutter, C. (2000), "Measuring Trust," Quarterly Journal of Economics, Vol. 115, pp. 811-846.

Glaeser, E., \& Saks, R. (2006), "Corruption in America," Journal of Public Economics, Vol. 90, pp. 1053-1072. 
Guiso, L., Sapienza, P., \& Zingales, L. (2004), "The Role of Social Capital in Financial Development," The American Economic Review, Vol. 94(3), pp. 526-556.

Guiso, L., Sapienza, P., \& Zingales, L. (2008a), "Trusting the Stock Market," Journal of Finance, Vol. 63(6), pp. 2557-2600.

Guiso, L., Sapienza, P., \& Zingales, L. (2008b), "Alfred Marshall Lecture Social Capital as Good Culture," Journal of the European Economic Association, Vol. 6(2-3), pp. 295-320.

Guiso, L., Sapienza, P., \& Zingales, L. (2009), "Cultural Biases in Economic Exchange?," The Quarterly Journal of Economics, Vol. 124(3), pp. 1095-1131.

Haggard, S., \& Tiede, L. (2011), "The Rule of Law and Economic Growth: Where Are We?," World Development, Vol. 39(5), pp. 673-685.

Hardin, R. (1991), "Trusting Persons, Trusting Institutions. In R. J. Zeckhauser (Ed.)," Strategy and Choice, pp. 185-209. Cambridge, MA: MIT Press.

Helliwell, J.F., and R. Putnam. (1995), "Economic Growth and Social Capital in Italy," Eastern Economic Journal, Vol. 21, pp. 295-307.

Heston, A., Summers, R., and Aten B., (2012), "Penn World Table Version 7.1, Center for International Comparisons of Production, Income and Prices at the University of Pennsylvania, Nov 2012.

Horváth, R. (2013), “Does Trust Promote Growth?," Journal of Comparative Economics, Vol. 41(3), pp. 777-788.

IMD. (1996 - 2011), World Competitiveness Yearbook, International Institute for Management Development, Lausanne, Switzerland.

Isham J. (2000), "The Effect of Social Capital on Technology Adoption: Evidence from Rural Tanzania," Middlebury College and WS Center Working Paper No 235.

Johnson, S., McMillan, J., \& Woodruff, C. (2002), "Property Rights and Finance," 
The American Economic Review, Vol. 92(5), pp. 1335-1356.

Keele, L. (2007), "Social Capital and the Dynamics of Trust in Government," American Journal of Political Science, Vol. 51(2), pp. 241-254.

Knack, S. (2001), Trust, Associational Life and Economic Performance. (published in) The Contribution of Human and Social Capital to Sustained Economic Growth and Well-Being: International Symposium Report, J. Helliwell (ed.), Quebec: Human Resources Development Canada. 2001.

Knack, S., and P. Keefer. (1995), "Institutions and Economic Performance: Cross-country Tests using Alternative Institutional Measures," Economics and Politics, Vol. 7, pp. 207-227.

Knack, S., and P. Keefer. (1997), "Does Social Capital have an Economic Pay-Off? A Cross-Country Investigation," Quarterly Journal of Economics, Vol. 112, pp. 1251-1288.

Kumar, M., \& Woo, J. (2010), "Public Debt and Growth," IMF Working Papers, pp. 1-47.

La Porta, R., Lopez-de-Silanes, F., Shleifer, A., \& Vishny, R. W. (1997), Trust in Large Organizations. The American Economic Review, 333-338.

Lazzarini, S. G., Madalozzo, R., Artes, R., \& de Oliveira Siqueira, J. (2005), "Measuring Trust: An Experiment in Brazil," Brazilian Journal of Applied Economics, Vol. 9(2), pp. 153-169.

Levine, R., and D. Renelt. (1992), "A Sensitivity Analysis of Cross-country Growth Regressions," American Economic Review, Vol. 82, pp. 942-963.

Ljunge, M. (2014), "Social Capital and Political Institutions: Evidence that Democracy Fosters Trust," Economics Letters, Vol. 122(1), pp. 44-49.

Mantzavinos, C., North, D. C., \& Shariq, S. (2004), "Learning, Institutions, and Economic Performance," Perspectives on Politics, Vol. 2(1), pp. 75-84.

Mauro, P. (1995), "Corruption and Growth," Quarterly Journal of Economics, Vol. 110, pp. 681-712. 
McKnight, D.H. and N.L. Chervany (1996), "The Meanings of Trust," University of Minnesota MIS Research, Working Paper Series, No. 96-04

Mercer. (2012), "Benefits Survey for Expatriates and Internationally Mobile Employees," retrieved from http://www.expatinfodesk.com/news/2012/08/02/ research-reveals-that-global-nomads-are-on-the-rise/

Mishler, W., \& Rose, R. (2001), "What are The Origins of Political Trust? Testing Institutional and Cultural Theories in Post-communist Societies," Comparative Political Studies, Vol. 34(1), pp. 30-62.

Moral-Benito, E. (2012), "Determinants of Economic Growth: A Bayesian Panel Data Approach,“ Review of Economics and Statistics, Vol. 94(2), pp. 566-579.

Nannestad, P., Svendsen, G. T., Dinesen, P. T., \& Sønderskov, K. M. (2014), "Do Institutions or Culture Determine the Level of Social Trust? The Natural Experiment of Migration from Non-western to Western Countries," Journal of Ethnic and Migration Studies, Vol. 40(4), pp. 544-565.

Nannicini, Tommaso, Andrea Stella, Guido Tabellini, and Ugo Troiano. (2013), "Social Capital and Political Accountability," American Economic Journal: Economic Policy, Vol. 5(2), pp. 222-250.

Newton, K. (1999), "Social and Political Trust in Established Democracies," In Pippa Norris(Ed.), Critical Citizens: Global Support for Democratic Governance, pp. 169-187, Oxford, UK: Oxford University Press.

Newton, K. (2001), "Trust, Social Capital, Civil Society, and Democracy," International Political Science Review, Vol. 22(2), pp. 201-214.

Norland, M. (2003), "Religion, Culture, and Economic Performance," Institute for International Economics, Working Paper Series No. 03-8.

North, Douglass C. (1990), Institutions, Institutional Change and Economic Performance, New York, Cambridge University Press.

North, Douglass C. (1998), "Where Have We Been and Where Are We Going? in 
Avner Bener and Louit Putterman (eds), Economics," Values and Organization, Cambridge: e4 Cambridge University Press

Putnam, R. (1993), Making Democracy Work. Civic Traditions in Modern Italy, Princeton, NJ: Princeton University Press.

Putnam, R. (2000), Bowling Alone. The Collapse and Revival of American Community, New York: Simon \& Schuster.

Reader's Digest (2001), Finders Keepers. Pleasantville, NY: Reader's Digest, April 2001.

Reeskens, T., \& Hooghe, M. (2008), “Cross-cultural Measurement Equivalence of Generalized Trust. Evidence from the European Social Survey (2002 and 2004)," Social Indicators Research, Vol. 85(3), pp. 515-532.

Rodrik, D., A. Sumbramanian, and F. Trebbi. (2004), "Institutions Rule: the Primacy of Institutions Over Geography and Integration in Economic Development," Journal of Economic Growth, Vol. 9, pp. 131-165.

Roodman, D. (2009), "How to do xtabond2: An Introduction to Difference and System GMM in Stata," Stata Journal, Vol. 9(1), p. 86.

Rothstein, B. (2000), "Trust, Social Dilemmas, and Collective Memories: On the Rise and Decline of the Swedish Model," Journal of Theoretical Politics, Vol. 12, pp. 477-499.

Sala-i-Martin, X. (1997), "I Just Ran Two Million Regressions," American Economic Review, May, pp. 178-183.

Sala-i-Martin, X., G. Doppelhofer, and R. Miller, (2004), "Determinants of Long-Term Growth: A Bayesian Averaging of Classical Estimates (BACE) Approach," American Economic Review, Vol. 94(4), pp. 813-835.

Sapienza, P., Toldra-Simats, A., \& Zingales, L. (2013), "Understanding Trust," The Economic Journal, Vol. 123(573), pp. 1313-1332.

Shapiro S.P. (1987), "The Social Control of Impersonal Trust," American Journal of Sociology, Vol. 93(3), pp. 623-658. 
Shin, Y., Noh Y., Lee D., Moon W. (2014), "Institutional Quality and Economic Growth," Economic Analysis, Vol. 20(3). pp. 75-110

Sturgis. P, Smith. P. (2010), "Assessing the Validity of Generalized Trust Questions: What Kind of Trust Are We Measuring?," International Journal of Public Opinion Research, Vol. 22, No. 1.

Tabellini, G. (2008), "The Scope Of Cooperation: Values And Incentives," Quarterly Journal of Economics, Vol. 123(3).

Tabellini, G. (2010), "Culture and Institutions: Economic Development in the Regions of Europe.," Journal of the European Economic Association, Vol. 8(4), pp. 677-716.

Tao, R., Yang, D. L., Li, M., \& Lu, X. (2014), "How Does Political Trust Affect Social Trust? An Analysis of Survey Data from Rural China using an Instrumental Variables Approach," International Political Science Review, Vol. 35(2), pp. 237-253.

Uslaner, E.M. (2002), The Moral Foundations of Trust. Cambridge, UK: Cambridge University Press.

Wang, L., \& Gordon, P. (2011), "Trust and Institutions: A Multi-level Analysis," The Journal of Socio-Economics, Vol. 40(5), pp. 583-593.

Whiteley, P. (2000), "Economic Growth and Social Capital," Political Studies, Vol. 48, pp. 443-466.

Williamson, O.E. (1993), "Calculativeness, Trust, and Economic Organization." Journal of Law and Economics, Vol. 34, pp. 453-502.

Woo, C., Kim, T., \& Jang, W. (2007), "Social Capital and Policy in Korea," Korea Development Institute, Working Paper No. 1.

World Bank. (2012), World Development Indicators. Washington DC: the World Bank. Yamagishi, T., \& Yamagishi, M. (1994), "Trust and Commitment in the United States and Japan," Motivation and Emotion, Vol. 18(2), pp. 129-166. 
Yamagishi, T., Cook, K. S., \& Watabe, M. (1998), "Uncertainty, Trust, and Commitment Formation in the United States and Japan 1," American Journal of Sociology, Vol. 104(1), pp. 165-194.

Young, C. (2009), "Model Uncertainty in Sociological Research: An Application to Religion and Economic Growth," American Sociological Review, Vol. 74(3), pp. 380-397.

Zak, P.J., and S. Knack. (2001), "Trust and Growth," The Economic Journal, Vol. 111, pp. 295-321.

Zak, P.J., and S. Knack. (2002), "Building Trust: Public Policy, Interpersonal Trust, and Economic Development," Supreme Court Economic Review, Vol. 10, pp. 91-107. 


\section{Appendix}

Table A1: List of 46 Countries \& the Average Growth Rate of real GDP per capita

\begin{tabular}{|c|c|c|c|c|c|c|}
\hline \multirow[b]{2}{*}{ Country } & \multirow{2}{*}{$\begin{array}{l}\text { Cross-section data } \\
\text { Average during } \\
\text { 1997-2012 }\end{array}$} & \multicolumn{5}{|c|}{ Panel data } \\
\hline & & $\begin{array}{c}T=1 \\
(1993- \\
1996)\end{array}$ & $\begin{array}{c}T=2 \\
(1997- \\
2000)\end{array}$ & $\begin{array}{c}\mathrm{T}=3 \\
(2001- \\
2004)\end{array}$ & $\begin{array}{c}T=4 \\
(2005- \\
2008)\end{array}$ & $\begin{array}{c}\mathrm{T}=5 \\
(2009- \\
2012)\end{array}$ \\
\hline Argentina & 2.73 & 2.58 & 1.00 & -0.44 & 7.06 & 4.02 \\
\hline Australia & 1.88 & 2.89 & 2.96 & 2.24 & 1.50 & 0.84 \\
\hline Austria & 1.60 & 1.64 & 3.16 & 1.01 & 2.28 & 0.03 \\
\hline Belgium & 1.20 & 1.22 & 2.98 & 1.18 & 1.42 & -0.70 \\
\hline Brazil & 1.72 & 2.53 & 0.48 & 1.29 & 3.40 & 1.83 \\
\hline Canada & 1.58 & 1.79 & 3.70 & 1.37 & 1.23 & 0.11 \\
\hline Chile & 2.95 & 5.85 & 2.03 & 2.78 & 4.06 & 3.02 \\
\hline China & 8.99 & 10.78 & 7.35 & 8.68 & 11.35 & 8.63 \\
\hline Colombia & 2.08 & 2.72 & -0.71 & 2.06 & 4.21 & 2.90 \\
\hline Czech Republic & 2.34 & 4.66 & 1.30 & 3.65 & 5.28 & -0.69 \\
\hline Denmark & 0.74 & 2.40 & 2.48 & 0.65 & 1.30 & -1.36 \\
\hline Finland & 2.10 & 2.20 & 4.86 & 2.29 & 2.80 & -1.30 \\
\hline France & 1.03 & 0.81 & 2.73 & 0.85 & 0.95 & -0.34 \\
\hline Germany & 1.50 & 0.71 & 2.04 & 0.42 & 2.39 & 1.24 \\
\hline Greece & 1.06 & 0.24 & 3.38 & 4.17 & 2.45 & -5.42 \\
\hline Hong Kong & 2.83 & 2.22 & 1.44 & 3.16 & 5.11 & 1.88 \\
\hline Hungary & 2.36 & 1.40 & 3.91 & 4.49 & 2.40 & -1.17 \\
\hline Iceland & 1.71 & 1.66 & 3.85 & 2.54 & 2.66 & -1.96 \\
\hline India & 5.17 & 4.53 & 3.77 & 4.41 & 6.53 & 6.07 \\
\hline Indonesia & 2.35 & 6.27 & -1.99 & 3.02 & 4.40 & 4.41 \\
\hline Ireland & 2.71 & 6.34 & 9.25 & 2.89 & 0.96 & -1.82 \\
\hline Israel & 1.70 & 3.01 & 2.47 & -0.30 & 3.24 & 1.48 \\
\hline Italy & 0.35 & 1.30 & 2.07 & 0.75 & 0.42 & -1.73 \\
\hline Japan & 0.55 & 1.12 & 0.20 & 0.99 & 0.98 & 0.12 \\
\hline Korea & 3.52 & 6.74 & 4.06 & 4.07 & 3.65 & 2.54 \\
\hline Luxembourg & 1.92 & 1.39 & 5.91 & 1.93 & 2.34 & -2.23 \\
\hline Malaysia & 2.31 & 6.84 & 1.09 & 2.10 & 3.77 & 2.60 \\
\hline Mexico & 1.32 & 0.11 & 3.43 & 0.05 & 1.29 & 0.68 \\
\hline Netherlands & 1.38 & 2.11 & 3.55 & 0.59 & 2.54 & -1.07 \\
\hline New Zealand & 1.46 & 3.38 & 2.00 & 2.50 & 1.06 & 0.34 \\
\hline
\end{tabular}




\section{BOK Working Paper No. 2017-15}

\begin{tabular}{lcccccc}
\hline Norway & 1.14 & 3.72 & 2.71 & 1.56 & 0.88 & -0.51 \\
Philippines & 2.35 & 2.11 & 0.72 & 2.37 & 3.12 & 3.32 \\
Poland & 4.15 & 5.47 & 5.45 & 3.01 & 5.49 & 2.70 \\
Portugal & 0.89 & 1.48 & 3.95 & 0.18 & 0.86 & -1.32 \\
Russia & 4.47 & -7.23 & 3.46 & 6.43 & 7.36 & 1.06 \\
Singapore & 2.99 & 5.82 & 3.00 & 3.35 & 2.90 & 3.18 \\
South Africa & 1.64 & 0.87 & 0.83 & 1.60 & 3.64 & 0.57 \\
Spain & 1.22 & 1.63 & 4.02 & 1.58 & 1.21 & -1.82 \\
Sweden & 2.09 & 1.85 & 3.89 & 2.21 & 1.86 & 0.55 \\
Switzerland & 1.11 & -0.26 & 2.09 & 0.28 & 2.33 & -0.20 \\
\hline Taiwan & 3.54 & 5.65 & 4.28 & 2.90 & 3.82 & 3.35 \\
Thailand & 2.09 & 7.03 & -1.37 & 3.92 & 3.83 & 2.41 \\
Turkey & 2.36 & 2.37 & 1.13 & 2.42 & 3.89 & 2.48 \\
United Kingdom & 1.48 & 3.61 & 3.49 & 2.49 & 1.51 & -1.45 \\
United States & 1.45 & 2.08 & 3.27 & 1.35 & 0.92 & 0.32 \\
Venezuela & 1.00 & -1.77 & -0.90 & -0.66 & 6.81 & -0.29 \\
\hline
\end{tabular}




\section{Table A2: Data Summary}

Panel A : Cross-section Data

\begin{tabular}{|c|c|c|c|c|c|c|c|}
\hline Variable & Detail / Classification & obs & Mean & S.D. & Min & Max & Source \\
\hline Growth (Growth rate) & $\begin{array}{c}\text { Average growth rate of real } \\
\text { percapitaGDPduring1997 2012 }\end{array}$ & 46 & 2.2 & 1.4 & 0.4 & 9.0 & IMF, WEO DB \\
\hline InY (Initial income) & In(per capita GDP in 1996(US\$) ) & 46 & 9.3 & 1.2 & 6.0 & 10.8 & IMF, WEO DB \\
\hline $\begin{array}{l}\text { P_inv (Relative price of } \\
\text { Investment) }\end{array}$ & $\begin{array}{c}\text { Price level of investment (relative to } \\
\text { the U.S.) in } 1996\end{array}$ & 46 & 78.5 & 23.5 & 32.6 & 134.7 & $\begin{array}{l}\text { Heston et al. } \\
\text { (2012), PWT } 7.1\end{array}$ \\
\hline $\begin{array}{l}\text { School (secondary } \\
\text { school enrollment) }\end{array}$ & $\begin{array}{l}\text { Secondary school enrollment rate in } \\
1995 \text { (population aged } 15 \text { and over) }\end{array}$ & 46 & 60.9 & 17.8 & 23.3 & 96.4 & $\begin{array}{l}\text { Barro \& Lee } \\
(2010)\end{array}$ \\
\hline $\begin{array}{l}\text { Gov/Y (Government } \\
\text { Share of GDP) }\end{array}$ & $\begin{array}{c}\text { General gov' t total expenditure / } \\
\text { GDP in1996 }\end{array}$ & 46 & 37.4 & 13.7 & 12.3 & 62.9 & IMF, WEO DB \\
\hline Open (Trade Openness) & $\begin{array}{c}(\text { Export+Import)/GDP } \\
\text { in1996 }\end{array}$ & 46 & 72.7 & 62.2 & 20.3 & 321.3 & $\begin{array}{l}\text { Heston et al. } \\
\text { (2012) }\end{array}$ \\
\hline Hierarchical & $\begin{array}{l}\text { Proportion of people belonging to } \\
\text { hierarchical religions defined by } \\
\text { Catholic and Islam as of } 1970 \text { 's }\end{array}$ & 46 & 0.4 & 0.4 & 0.00 & 0.99 & $\begin{array}{l}\text { Barro, Religion } \\
\text { Adherence Data } \\
\text { (2003) }\end{array}$ \\
\hline Justice & \multirow{3}{*}{ Institutional Trust } & 46 & 5.6 & 2.3 & 0.8 & 8.7 & IMD, WCY (1996) \\
\hline PropertyRights & & 46 & 5.8 & 2.4 & 0.4 & 9.4 & IMD, WCY (1996) \\
\hline LegalSystem & & 42 & 5.0 & 2.0 & 1.5 & 8.9 & $\begin{array}{c}\text { WVS } \\
\text { (1995-98 wave) }\end{array}$ \\
\hline MostPeople & Interpersonal Trust & 46 & 5.0 & 2.0 & 1.6 & 9.5 & $\begin{array}{c}\text { WVS } \\
\text { (1995-98 wave) }\end{array}$ \\
\hline GovernmentPolicy & \multirow{4}{*}{ Political Trust } & 46 & 4.8 & 1.5 & 1.0 & 8.7 & IMD, WCY (1996) \\
\hline Government & & 35 & 5.0 & 2.0 & 2.0 & 10.0 & $\begin{array}{c}\text { WVS } \\
\text { (1995-98 wave) }\end{array}$ \\
\hline PoliticalParty1 & & 46 & 4.7 & 1.6 & 0.7 & 8.2 & IMD, WCY (2002) \\
\hline PoliticalParty2 & & 35 & 5.0 & 2.0 & 1.4 & 9.9 & $\begin{array}{c}\text { WVS } \\
\text { (1995-98 wave) }\end{array}$ \\
\hline
\end{tabular}

Notes: The largest number of countries for which both IMD data and WVS data are available is 46 . For the countries where WVS 1995-98 wave (third wave) is not available, the author fills in the fourth or fifth wave result. 


\section{Table A2 (Cont.)}

Panel B: Panel Data

\begin{tabular}{|c|c|c|c|c|c|c|c|}
\hline Variable & $\begin{array}{c}\text { Detail ( } 4 \text { year non-overlapping } \\
\text { average } \times 5 \text { periods ( } 20 \text { years), } \\
46 \text { countries) }\end{array}$ & $\begin{array}{l}\text { obs } \\
\left(N^{*} T\right)\end{array}$ & Mean & S.D. & Min & Max & Source \\
\hline Growth $_{i, t}$ & $\begin{array}{l}\text { Growth rate of real } \\
\text { percapitaGDP }\end{array}$ & 230 & 2.3 & 2.4 & -7.2 & 11.3 & $\begin{array}{l}\text { Heston et al. } \\
(2012)^{\mathrm{a}} \& \text { IMF } \\
\text { WEO DB }\end{array}$ \\
\hline$P_{-}$inv $i, t$ & $\begin{array}{l}\text { Price level of investment } \\
\text { (relative to the U.S.) }\end{array}$ & 230 & 75.6 & 22.5 & 30.7 & 134.6 & $\begin{array}{l}\text { Heston et al. } \\
(2012)\end{array}$ \\
\hline$P_{0} p_{i, t}$ & Population (in milions) & 230 & 95.4 & 236.9 & 0.3 & 1326.9 & $"$ \\
\hline Share_Inv $i, t$ & Share of Investment / GDP & 230 & 24.5 & 6.0 & 12.2 & 50.1 & $"$ \\
\hline Share_Gov i,t & $\begin{array}{c}\text { Share of Government Consumption } \\
\text { / GDP }\end{array}$ & 230 & 7.1 & 2.6 & 2.9 & 18.1 & $"$ \\
\hline Openness $_{i, t}$ & (Export+lmport)/GDP & 230 & 87.4 & 73.5 & 18.4 & 425.7 & $"$ \\
\hline Justice $_{i, t}^{b}$ & \multirow{2}{*}{ Institutional Trust } & 230 & 5.8 & 2.2 & 0.7 & 9.0 & \multirow{2}{*}{$\begin{array}{c}\text { IMD, WCY } \\
(1996-2011)\end{array}$} \\
\hline Property Rights ${ }_{i, t}^{b}$ & & 230 & 6.3 & 2.2 & 0.4 & 9.4 & \\
\hline
\end{tabular}

Notes: This table provides summary statistics for the panel data analysis. Panel data sets are averaged over four-year non-overlapping periods between 1993 and 2012. The panel data has $\mathrm{T}=5, \mathrm{~N}=46$ structure. The first observation of the panel data represents the average value during 1993 1996. The second observation of the panel represents the average value during 1997-2000 and so on... The fifth observation of the panel represents the average value during 2009-2012.

a) As the PWT 7.1 provides country-level panel data up to 2010, the real per capita GDP growth rate of 2011 and 2012 are obtained from the IMF database. In the case of missing data sets from PWT 7.1 where alternative sources for the variable are not available, the fifth observation is based on the 2-year average (2009-2010).

b) In the case of the trust index, the IMD survey on Justice and Property Rights is available from 1996 to 2011. Hence, the first observation of the trust index in the panel is based on one year (1996) survey results. The second, third, and fourth observations of the trust index in the panel are based on 4-year average figures. The fifth observation of the trust index is based on the 3-year average (2009-2011). 


\section{Table A3: Spearman Rank Correlation Coefficient between Trust Indices}

\begin{tabular}{|c|c|c|c|c|c|c|c|c|c|}
\hline & Source & & 11 & & & & $\mathrm{~W} \vee$ & & \\
\hline & Trust Index & Justice & $\begin{array}{c}\text { Property } \\
\text { Rights }\end{array}$ & $\begin{array}{c}\text { Government } \\
\text { policy }\end{array}$ & $\begin{array}{l}\text { Political } \\
\text { Party1 }\end{array}$ & $\begin{array}{c}\text { Most } \\
\text { People }\end{array}$ & $\begin{array}{l}\text { Legal } \\
\text { System }\end{array}$ & $\begin{array}{c}\text { Govern } \\
\text { ment }\end{array}$ & $\begin{array}{l}\text { Political } \\
\text { Party2 }\end{array}$ \\
\hline & Classification & Institutior & nal trust & $\begin{array}{l}\text { (Ability-1 } \\
\text { Politica }\end{array}$ & $\begin{array}{l}\text { Dased) } \\
\text { ltrust }\end{array}$ & $\begin{array}{l}\text { Interpersonal } \\
\text { trust }\end{array}$ & $\begin{array}{l}\text { Institutional } \\
\text { trust }\end{array}$ & $\begin{array}{l}\text { (Ove } \\
\text { Politice }\end{array}$ & $\begin{array}{l}\text { all) } \\
\text { |ltrust }\end{array}$ \\
\hline & Justice & 1.000 & & & & & & & \\
\hline & PropertyRights & $0.866^{* * *}$ & 1.000 & & & & & & \\
\hline & GovernmentPolicy & 0.204 & 0.063 & 1.000 & & & & & \\
\hline & PoliticalParty1 & $0.611^{* * *}$ & $0.430^{* *}$ & 0.173 & 1.000 & & & & \\
\hline & MostPeople & $0.688^{* * *}$ & $0.719^{* * *}$ & 0.131 & $0.310^{*}$ & 1.000 & & & \\
\hline$\sum$ & LegalSystem & $0.449 * * *$ & $0.382^{* * *}$ & 0.049 & 0.043 & 0.187 & 1.000 & & \\
\hline & Government & 0.134 & 0.109 & $0.301^{*}$ & -0.006 & 0.013 & $0.683^{* * *}$ & 1.000 & \\
\hline & PoliticalParty2 & $0.298^{*}$ & 0.283 & 0.160 & 0.121 & $0.343^{*}$ & $0.557^{* * *}$ & $0.759^{* * *}$ & 1.000 \\
\hline
\end{tabular}

Notes: Levels of significance: $* * * 1 \%, * * 5 \%, * 10 \%$. Sample size is 32 (The largest number of countries that all IMD trust indices and WVS indices are available is 32). IMD data (Justice, Property Right, GovernmentPolicy) are based on 1996 survey result. PoliticalParty1 is based on the 2002 survey (survey questions on PoliticalParty1 were introduced in 2002). WVS data are based on the third wave survey conducted in 1995-1997. For countries where the third wave survey are not conducted, the forth or fifth wave survey is used.

Sources: IMD, World Competitiveness Yearbook 1996, 2002; World Values Survey, mainly the 1995-1998 wave

Table A4: Principal Component Analysis by Classification of Trust Indices

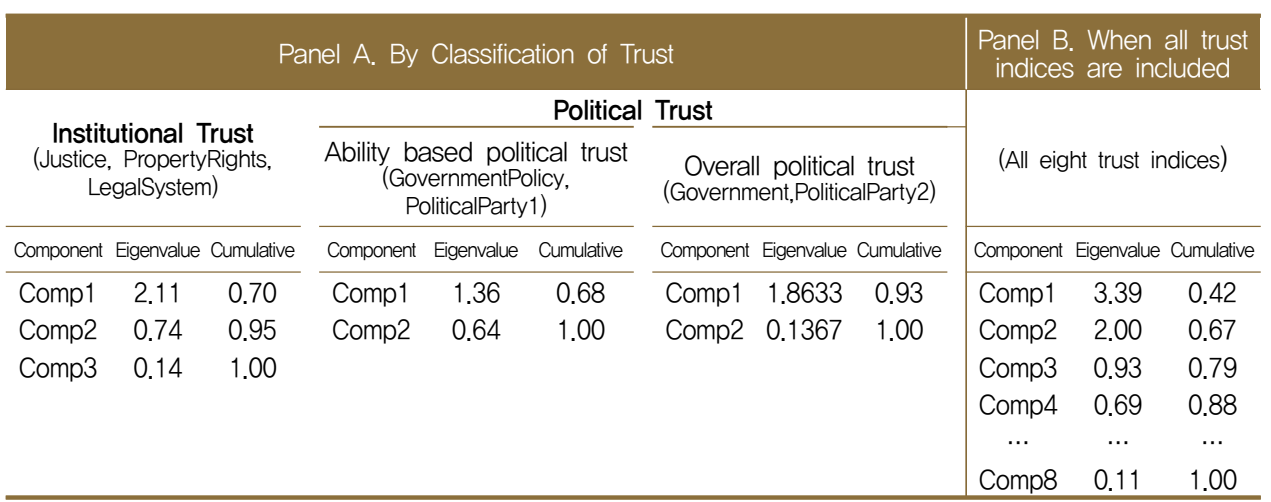

Notes: The number of observations of Panel $A$ is 42, 46, and 35 respectively, which is the number of countries in which all data are available. The number of observations of Panel B is 33 . There are several criteria for determining the appropriate number of factors. The Kaiser criterion suggests to retain factors with eigenvalues greater than one. The variance explained criterion suggests keeping enough factors to account for $90 \%$ or $80 \%$ of the total variation. 
Table A5: OLS Robustness Check 1: Additional Covariates and Regional Dummies were included

\begin{tabular}{|c|c|c|c|c|c|c|c|c|}
\hline & (1) & (2) & (3) & (4) & (5) & (6) & (7) & (8) \\
\hline $\ln Y_{96}$ & $\begin{array}{c}-1.097^{* * *} \\
(0.282)\end{array}$ & $\begin{array}{c}-1.137^{* * *} \\
(0.319)\end{array}$ & $\begin{array}{c}-1.040^{* * *} \\
(0.327)\end{array}$ & $\begin{array}{c}-1.060^{* * *} \\
(0.280)\end{array}$ & $\begin{array}{c}-1.005^{* * *} \\
(0.318)\end{array}$ & $\begin{array}{c}-0.804^{* * *} \\
(0.271)\end{array}$ & $\begin{array}{c}* 1.109^{* * *} \\
(0.316)\end{array}$ & $\begin{array}{c}-0.846^{* * *} \\
(0.265)\end{array}$ \\
\hline P_inv96 & $\begin{array}{l}-0.0104 \\
(0.0126)\end{array}$ & $\begin{array}{c}-0.00878 \\
(0.0122)\end{array}$ & $\begin{array}{r}-0.00386 \\
(0.0138)\end{array}$ & $\begin{array}{c}-0.00570 \\
(0.0116)\end{array}$ & $\begin{array}{c}-0.00572 \\
(0.0121)\end{array}$ & $\begin{array}{r}-0.00723 \\
(0.0104)\end{array}$ & $\begin{array}{c}-0.000422 \\
(0.0115)\end{array}$ & $\begin{array}{c}-0.00600 \\
(0.0100)\end{array}$ \\
\hline School 95 & $\begin{array}{l}0.0168^{* *} \\
(0.00820)\end{array}$ & $\begin{array}{l}0.0219^{* * *} \\
(0.00789)\end{array}$ & $\begin{array}{l}0.0227^{* *} \\
(0.00862)\end{array}$ & $\begin{array}{c}0.0159^{*} \\
(0.00858)\end{array}$ & $\begin{array}{l}0.0175^{* *} \\
(0.00805)\end{array}$ & $\begin{array}{l}0.0206^{* *} \\
(0.00793)\end{array}$ & $\begin{array}{l}0.0147^{*} \\
(0.00772)\end{array}$ & $\begin{array}{l}0.0224^{* * *} \\
(0.00783)\end{array}$ \\
\hline Gov/Y 96 & $\begin{array}{l}0.0174 \\
(0.0153)\end{array}$ & $\begin{array}{l}0.0195 \\
(0.0147)\end{array}$ & $\begin{array}{l}0.0184 \\
(0.0150)\end{array}$ & $\begin{array}{l}0.0230 \\
(0.0166)\end{array}$ & $\begin{array}{l}0.0232 \\
(0.0152)\end{array}$ & $\begin{array}{l}0.00762 \\
(0.0167)\end{array}$ & $\begin{array}{l}0.0154 \\
(0.0154)\end{array}$ & $\begin{array}{l}0.00659 \\
(0.0152)\end{array}$ \\
\hline open $_{96}$ & $\begin{array}{l}0.00498^{* *} \\
(0.00246)\end{array}$ & $\begin{array}{l}0.00538^{* *} \\
(0.00242)\end{array}$ & $\begin{array}{l}0.00472 \\
(0.00463)\end{array}$ & $\begin{array}{c}0.00778^{* * *} \\
(0.00244)\end{array}$ & $\begin{array}{l}0.00506^{*} \\
(0.00277)\end{array}$ & $\begin{array}{l}0.00450 \\
(0.00352)\end{array}$ & $\begin{array}{l}0.00534^{* *} \\
(0.00227)\end{array}$ & $\begin{array}{c}0.00516 \\
(0.00368)\end{array}$ \\
\hline East_asia & $\begin{array}{l}2.189^{* *} \\
(0.937)\end{array}$ & $\begin{array}{l}1.945^{* *} \\
(0.949)\end{array}$ & $\begin{array}{l}1.953^{*} \\
(1.039)\end{array}$ & $\begin{array}{l}2.043^{* *} \\
(0.939)\end{array}$ & $\begin{array}{l}2.396^{* *} \\
(1.060)\end{array}$ & $\begin{array}{l}1.096 \\
(0.660)\end{array}$ & $\begin{array}{l}2.205^{* *} \\
(0.866)\end{array}$ & $\begin{array}{l}1.114^{*} \\
(0.649)\end{array}$ \\
\hline Nordic & $\begin{array}{l}0.0984 \\
(0.393)\end{array}$ & $\begin{array}{l}0.168 \\
(0.406)\end{array}$ & $\begin{array}{l}0.116 \\
(0.539)\end{array}$ & $\begin{array}{l}-0.323 \\
(0.585)\end{array}$ & $\begin{array}{l}0.253 \\
(0.445)\end{array}$ & $\begin{array}{l}0.723 \\
(0.496)\end{array}$ & $\begin{array}{c}0.164 \\
(0.411)\end{array}$ & $\begin{array}{l}0.760^{*} \\
(0.440)\end{array}$ \\
\hline Justice $_{96}$ & $\begin{array}{l}0.195^{*} \\
(0.102)\end{array}$ & & & & & & & \\
\hline PropertyRights96 & & $\begin{array}{l}0.149^{*} \\
(0.0855)\end{array}$ & & & & & & \\
\hline LegalSystem 96 & & & $\begin{array}{c}0.0825 \\
(0.0952)\end{array}$ & & & & & \\
\hline$\left[\right.$ MostPeopleg6 $_{96}$ & & & & $\begin{array}{l}0.165 \\
(0.114)\end{array}$ & & & & \\
\hline GovernmentPolicy 96 & & & & & $\begin{array}{l}0.158 \\
(0.119)\end{array}$ & & & \\
\hline Government96 & & & & & & $\begin{array}{l}-0.0505 \\
(0.104)\end{array}$ & & \\
\hline PoliticalParty $1_{02}$ & & & & & & & $\begin{array}{l}0.218 \\
(0.161)\end{array}$ & \\
\hline PoliticalParty2 ${ }_{96}$ & & & & & & & & $\begin{array}{l}-0.0841 \\
(0.113)\end{array}$ \\
\hline Constant & $\begin{array}{l}9.813^{* * *} \\
(1.752)\end{array}$ & $\begin{array}{c}9.868^{* * *} \\
(1.956)\end{array}$ & $\begin{array}{c}9.060^{* * *} \\
(2.109)\end{array}$ & $\begin{array}{c}9.052^{* * *} \\
(1.700)\end{array}$ & $\begin{array}{c}8.628^{* * *} \\
(2.096)\end{array}$ & $\begin{array}{c}8.275^{* * *} \\
(1.995)\end{array}$ & $\begin{array}{c}9.382^{* * *} \\
(1.783) \\
\end{array}$ & $\begin{array}{c}8.608^{* * *} \\
(1.928)\end{array}$ \\
\hline Observations & 46 & 46 & 42 & 46 & 46 & 35 & 46 & 35 \\
\hline R-squared & 0.684 & 0.664 & 0.659 & 0.663 & 0.649 & 0.554 & 0.672 & 0.564 \\
\hline
\end{tabular}

Notes: The dependent variable is the average growth rate of real GDP per capita during 1997-2012. Heteroskedasticity robust standard error in parentheses. Levels of significance: ${ }^{* * *} 1 \%,{ }^{* *} 5 \%, * 10 \%$. 
Table A6: OLS Robustness Check 2: A quantile (median) regression is used

\begin{tabular}{|c|c|c|c|c|c|c|c|c|}
\hline & (1) & (2) & (3) & (4) & (5) & (6) & (7) & (8) \\
\hline \multirow[t]{2}{*}{$\ln Y_{96}$} & $-0.668^{* *}$ & $-0.730^{* *}$ & $-0.566^{*}$ & -0.235 & -0.326 & -0.371 & -0.505 & -0.382 \\
\hline & $(0.255)$ & $(0.295)$ & $(0.327)$ & $(0.258)$ & $(0.290)$ & $(0.333)$ & $(0.331)$ & $(0.314)$ \\
\hline \multirow{2}{*}{ P_inv96 } & $-0.0223^{*}$ & -0.0187 & -0.00659 & -0.0157 & -0.00937 & -0.00521 & -0.00376 & -0.00526 \\
\hline & $(0.0112)$ & $(0.0125)$ & $(0.0153)$ & $(0.0123)$ & $(0.0134)$ & $(0.0141)$ & $(0.0148)$ & $(0.0130)$ \\
\hline \multirow[t]{2}{*}{ School95 } & 0.00830 & 0.0103 & $0.0242^{*}$ & 0.0116 & 0.0130 & 0.0107 & 0.00641 & 0.0113 \\
\hline & $(0.0111)$ & $(0.0125)$ & $(0.0130)$ & $(0.0122)$ & $(0.0130)$ & $(0.0140)$ & $(0.0144)$ & $(0.0133)$ \\
\hline \multirow[t]{2}{*}{ Justice 96} & $0.354^{* * *}$ & & & & & & & \\
\hline & $(0.0935)$ & & & & & & & \\
\hline \multirow[t]{2}{*}{ PropertyRights 96} & & $0.268^{* *}$ & & & & & & \\
\hline & & $(0.100)$ & & & & & & \\
\hline \multirow{2}{*}{ LegalSystem 96} & & & 0.168 & & & & & \\
\hline & & & $(0.104)$ & & & & & \\
\hline \multirow{2}{*}{ MostPeople 96} & & & & 0.0484 & & & & \\
\hline & & & & $(0.0993)$ & & & & \\
\hline \multirow[t]{2}{*}{ GovernmentPolicy 96} & & & & & $0.239^{*}$ & & & \\
\hline & & & & & $(0.137)$ & & & \\
\hline \multirow[t]{2}{*}{ Government96 } & & & & & & 0.0204 & & \\
\hline & & & & & & $(0.115)$ & & \\
\hline \multirow[t]{2}{*}{ PoliticalParty $1_{02}$} & & & & & & & 0.148 & \\
\hline & & & & & & & $(0.156)$ & \\
\hline PoliticalParty $2_{96}$ & & & & & & & & 0.0207 \\
\hline - & & & & & & & & $(0.106)$ \\
\hline \multirow[t]{2}{*}{ Constant } & $7.317^{* * *}$ & $8.090^{* * *}$ & $5.369^{* *}$ & $4.345^{* *}$ & $3.561^{*}$ & $4.900^{* *}$ & $5.673^{* * *}$ & $4.963^{* *}$ \\
\hline & $(1.562)$ & $(1.760)$ & (2.122) & $(1.629)$ & $(1.792)$ & $(2.215)$ & $(1.935)$ & $(2.075)$ \\
\hline Observations & 46 & 46 & 42 & 46 & 46 & 35 & 46 & 35 \\
\hline
\end{tabular}

Notes: The dependent variable is the average growth rate of real GDP per capita during 1997-2012. Standard error in parentheses. Levels of significance: *** $1 \%, * * 5 \%, * 10 \%$. This table shows the results when median regression is employed. 
Table A7: OLS Robustness Check 3: China is excluded from the sample

\begin{tabular}{|c|c|c|c|c|c|c|c|c|}
\hline & (1) & (2) & (3) & (4) & (5) & (6) & (7) & (8) \\
\hline $\ln Y_{96}$ & $\begin{array}{c}-0.581^{* * *} \\
(0.190)\end{array}$ & $\begin{array}{c}-0.643^{* * *} \\
(0.196)\end{array}$ & $\begin{array}{c}-0.593^{* * *} \\
(0.204)\end{array}$ & $\begin{array}{c}-0.446^{* *} \\
(0.182)\end{array}$ & $\begin{array}{c}-0.518^{* * *} \\
(0.177)\end{array}$ & $\begin{array}{c}-0.603^{* * *} \\
(0.219)\end{array}$ & $\begin{array}{c}-0.490^{* *} \\
(0.209)\end{array}$ & $\begin{array}{l}-0.606^{* *} \\
(0.222)\end{array}$ \\
\hline P_inv 96 & $\begin{array}{l}-0.0162^{* *} \\
(0.00787)\end{array}$ & $\begin{array}{l}-0.0154^{*} \\
(0.00771)\end{array}$ & $\begin{array}{l}-0.00955 \\
(0.00928)\end{array}$ & $\begin{array}{l}-0.0158^{*} \\
(0.00839)\end{array}$ & $\begin{array}{l}-0.0105 \\
(0.00788)\end{array}$ & $\begin{array}{l}-0.00786 \\
(0.00925)\end{array}$ & $\begin{array}{l}-0.0129 \\
(0.00858)\end{array}$ & $\begin{array}{l}-0.00888 \\
(0.00918)\end{array}$ \\
\hline School 95 & $\begin{array}{l}0.0192^{* *} \\
(0.00785)\end{array}$ & $\begin{array}{l}0.0228^{* * *} \\
(0.00786)\end{array}$ & $\begin{array}{l}0.0246 * * * \\
(0.00801)\end{array}$ & $\begin{array}{l}0.0186^{* *} \\
(0.00827)\end{array}$ & $\begin{array}{l}0.0200^{* *} \\
(0.00774)\end{array}$ & $\begin{array}{l}0.0230^{* *} \\
(0.00924)\end{array}$ & $\begin{array}{l}0.0191^{* *} \\
(0.00826)\end{array}$ & $\begin{array}{l}0.0228^{* *} \\
(0.00940)\end{array}$ \\
\hline [Justice 96 & $\begin{array}{l}0.127^{*} \\
(0.0678)\end{array}$ & & & & & & & \\
\hline PropertyRights96 & & $\begin{array}{l}0.140^{* *} \\
(0.0646)\end{array}$ & & & & & & \\
\hline LegalSystem 96 & & & $\begin{array}{c}0.104 \\
(0.0662)\end{array}$ & & & & & \\
\hline$\left[\right.$ MostPeople $_{96}$ & & & & $\begin{array}{l}0.0517 \\
(0.0716)\end{array}$ & & & & \\
\hline [ GovernmentPolicy 96 & & & & & $\begin{array}{l}0.176^{* *} \\
(0.0810)\end{array}$ & & & \\
\hline Government96 & & & & & & $\begin{array}{c}0.0467 \\
(0.0759)\end{array}$ & & \\
\hline PoliticalParty $1_{02}$ & & & & & & & $\begin{array}{c}0.0453 \\
(0.0972)\end{array}$ & \\
\hline PoliticalParty296 & & & & & & & & $\begin{array}{l}0.00665 \\
(0.0746)\end{array}$ \\
\hline Constant & $\begin{array}{c}6.816^{* * *} \\
(1.197)\end{array}$ & $\begin{array}{c}7.016^{* * *} \\
(1.196)\end{array}$ & $\begin{array}{l}6.232^{* * *} \\
(1.314)\end{array}$ & $\begin{array}{c}6.020^{* * *} \\
(1.166)\end{array}$ & $\begin{array}{c}5.592^{* * *} \\
(1.129)\end{array}$ & $\begin{array}{c}6.569^{* * *} \\
(1.459)\end{array}$ & $\begin{array}{l}6.213^{* * *} \\
(1.221)\end{array}$ & $\begin{array}{c}6.881^{* * *} \\
(1.464)\end{array}$ \\
\hline Observations & 45 & 45 & 41 & 45 & 45 & 35 & 45 & 35 \\
\hline R-squared & 0.468 & 0.482 & 0.503 & 0.428 & 0.482 & 0.470 & 0.424 & 0.463 \\
\hline
\end{tabular}

Notes: The dependent variable is the average growth rate of real GDP per capita during 1997-2012.

Standard error in parentheses. (Results of Breusch-Pagan / Cook-Weisberg test for heteroskedasticity shows that there is no heteroskedasticity at $5 \%$ level except for column (5)). Levels of significance: *** $1 \%$, ** $5 \%$, * $10 \%$ 
Table A8: OLS Robustness Check 4: Sample countries are restricted to 42 countries

\begin{tabular}{|c|c|c|c|c|c|c|c|c|}
\hline & (1) & (2) & (3) & (4) & (5) & (6) & (7) & (8) \\
\hline $\ln Y_{96}$ & $\begin{array}{c}-1.076^{* * *} \\
(0.262)\end{array}$ & $\begin{array}{c}-1.191^{* * *} \\
(0.260)\end{array}$ & $\begin{array}{c}-0.841^{* * *} \\
(0.264)\end{array}$ & $\begin{array}{c}-0.917^{* * *} \\
(0.265)\end{array}$ & $\begin{array}{c}-0.989 * * * \\
(0.277)\end{array}$ & $\begin{array}{c}-0.782^{* * *} \\
(0.257)\end{array}$ & $\begin{array}{c}-1.236^{* * *} \\
(0.285)\end{array}$ & $\begin{array}{c}-0.802^{* * *} \\
(0.262)\end{array}$ \\
\hline P_inv96 & $\begin{array}{l}-0.0124 \\
(0.0127)\end{array}$ & $\begin{array}{l}-0.0113 \\
(0.0120)\end{array}$ & $\begin{array}{l}-0.0101 \\
(0.0124)\end{array}$ & $\begin{array}{l}-0.0110 \\
(0.0128)\end{array}$ & $\begin{array}{c}-0.00314 \\
(0.0129)\end{array}$ & $\begin{array}{c}-0.000532 \\
(0.0108)\end{array}$ & $\begin{array}{l}0.00562 \\
(0.0128)\end{array}$ & $\begin{array}{c}-0.000770 \\
(0.0109)\end{array}$ \\
\hline School $_{95}$ & $\begin{array}{l}0.0273^{* *} \\
(0.0106)\end{array}$ & $\begin{array}{c}0.0336^{* * *} \\
(0.0102)\end{array}$ & $\begin{array}{l}0.0324^{* * *} \\
(0.0105)\end{array}$ & $\begin{array}{l}0.0245^{* *} \\
(0.0110)\end{array}$ & $\begin{array}{l}0.0299 * * \\
(0.0112)\end{array}$ & $\begin{array}{l}0.0255^{* *} \\
(0.00935)\end{array}$ & $\begin{array}{l}0.0239^{* *} \\
(0.0109)\end{array}$ & $\begin{array}{l}0.0256^{* *} \\
(0.00956)\end{array}$ \\
\hline [ Justice 96 & $\begin{array}{l}0.227^{* *} \\
(0.0955)\end{array}$ & & & & & & & \\
\hline PropertyRights96 & & $\begin{array}{l}0.259^{* * *} \\
(0.0880)\end{array}$ & & & & & & \\
\hline LegalSystem 96 & & & $\begin{array}{l}0.209^{* *} \\
(0.0843)\end{array}$ & & & & & \\
\hline$\left[\right.$ MostPeopleg6 $_{9}$ & & & & $\begin{array}{l}0.199 * * \\
(0.0939)\end{array}$ & & & & \\
\hline [ GovernmentPolicy 96 & & & & & $\begin{array}{l}0.0974 \\
(0.139)\end{array}$ & & & \\
\hline Government 96 & & & & & & $\begin{array}{c}0.0507 \\
(0.0847)\end{array}$ & & \\
\hline PoliticalParty $1_{02}$ & & & & & & & $\begin{array}{l}0.294^{* *} \\
(0.132)\end{array}$ & \\
\hline PoliticalParty296 & & & & & & & & $\begin{array}{c}-0.000660 \\
(0.0829)\end{array}$ \\
\hline Constant & $\begin{array}{c}10.16^{* * *} \\
(1.549)\end{array}$ & $\begin{array}{c}10.53^{* * *} \\
(1.511)\end{array}$ & $\begin{array}{c}7.679^{* * *} \\
(1.715)\end{array}$ & $\begin{array}{c}8.964^{* * *} \\
(1.585)\end{array}$ & $\begin{array}{c}9.247^{* * *} \\
(1.722)\end{array}$ & $\begin{array}{c}7.429^{* * *} \\
(1.644)\end{array}$ & $\begin{array}{c}10.28^{* * *} \\
(1.571)\end{array}$ & $\begin{array}{c}7.881^{* * *} \\
(1.650)\end{array}$ \\
\hline Observations & 42 & 42 & 42 & 42 & 42 & 33 & 42 & 33 \\
\hline R-squared & 0.563 & 0.593 & 0.569 & 0.551 & 0.504 & 0.503 & 0.557 & 0.496 \\
\hline
\end{tabular}

Notes: The dependent variable is the average growth rate of real GDP per capita during 1997-2012. Heteroskedasticity robust standard error in parentheses. Levels of significance: *** $1 \%, * * 5 \%, * 10 \%$. 
Table A9: OLS Robustness Check 5: Schooling variable excluded

\begin{tabular}{|c|c|c|c|c|c|c|c|c|}
\hline & (1) & (2) & (3) & (4) & (5) & (6) & (7) & (8) \\
\hline \multirow[t]{2}{*}{$\ln Y_{96}$} & $-0.768^{* *}$ & $-0.760^{* *}$ & $-0.543^{*}$ & $-0.541^{*}$ & $-0.592^{*}$ & -0.331 & $-0.825^{*}$ & -0.332 \\
\hline & $(0.343)$ & $(0.361)$ & $(0.292)$ & $(0.279)$ & $(0.301)$ & $(0.216)$ & $(0.415)$ & $(0.215)$ \\
\hline \multirow{2}{*}{$P_{-}$inv 96} & $-0.0170^{*}$ & -0.0151 & -0.0118 & $-0.0202^{* *}$ & -0.0101 & -0.0106 & -0.00445 & -0.0112 \\
\hline & $(0.00854)$ & $(0.00903)$ & $(0.0123)$ & $(0.00859)$ & $(0.00937)$ & $(0.00927)$ & $(0.0126)$ & $(0.00916)$ \\
\hline \multirow[t]{2}{*}{ Justice $_{96}$} & $0.243^{*}$ & & & & & & & \\
\hline & $(0.123)$ & & & & & & & \\
\hline \multirow[t]{2}{*}{ PropertyRights96 } & & $0.214^{*}$ & & & & & & \\
\hline & & $(0.127)$ & & & & & & \\
\hline LegalSystem $_{96}$ & & & 0.186 & & & & & \\
\hline L & & & $(0.121)$ & & & & & \\
\hline \multirow{2}{*}{ MostPeople $_{96}$} & & & & 0.224 & & & & \\
\hline & & & & $(0.136)$ & & & & \\
\hline \multirow[t]{2}{*}{ [ GovernmentPolicy } & & & & & 0.128 & & & \\
\hline & & & & & (0.113) & & & \\
\hline \multirow[t]{2}{*}{ Government96 } & & & & & & 0.0455 & & \\
\hline & & & & & & $(0.0947)$ & & \\
\hline \multirow[t]{2}{*}{ PoliticalParty $1_{02}$} & & & & & & & 0.300 & \\
\hline & & & & & & & $(0.195)$ & \\
\hline PoliticalParty296 & & & & & & & & 0.0333 \\
\hline L & & & & & & & & $(0.0909)$ \\
\hline \multirow[t]{2}{*}{ Constant } & $9.235^{* * *}$ & $9.135^{* * *}$ & $7.153^{* * *}$ & $7.635^{* * *}$ & $7.825^{* * *}$ & $5.709^{* * *}$ & $8.750^{* * *}$ & $5.827^{* * *}$ \\
\hline & $(2.597)$ & $(2.675)$ & $(2.113)$ & $(2.048)$ & $(2.729)$ & $(1.871)$ & $(2.457)$ & $(1.726)$ \\
\hline Observations & 46 & 46 & 42 & 46 & 46 & 35 & 46 & 35 \\
\hline R-squared & 0.469 & 0.456 & 0.458 & 0.460 & 0.394 & 0.360 & 0.461 & 0.358 \\
\hline
\end{tabular}

Notes: The dependent variable is the average growth rate of real GDP per capita during 1997-2012.

Heteroskedasticity robust standard error in parentheses. Levels of significance: ${ }^{* *} 1 \%, * * 5 \%, * 10 \%$. 
Table A10: 2SLS Robustness Check ( $2^{\text {nd }}$ stage results): Regional Dummy + More covariates

\begin{tabular}{|c|c|c|c|c|c|c|c|c|}
\hline & (1) & (2) & (3) & (4) & (5) & (6) & (7) & (8) \\
\hline \multirow[t]{2}{*}{$\ln Y_{96}$} & $-0.988^{* * *}$ & $-1.341^{* * *}$ & $-0.672^{*}$ & $-0.917^{* * *}$ & $-1.069^{* *}$ & -0.476 & $-1.102^{* * *}$ & -0.344 \\
\hline & $(0.315)$ & $(0.406)$ & $(0.361)$ & $(0.278)$ & $(0.448)$ & $(0.350)$ & $(0.342)$ & $(0.433)$ \\
\hline \multirow[t]{2}{*}{ P_inv 96} & -0.00891 & -0.0196 & -0.0158 & -0.00966 & 0.00905 & -0.00853 & 0.00399 & -0.0144 \\
\hline & $(0.0116)$ & $(0.0137)$ & $(0.0155)$ & (0.00989) & $(0.0202)$ & $(0.0107)$ & $(0.0125)$ & $(0.0151)$ \\
\hline \multirow[t]{2}{*}{ School 95} & $0.0268^{* * *}$ & $0.0338^{* * *}$ & $0.0348^{* * *}$ & $0.0232^{* *}$ & $0.0360^{* *}$ & $0.0212^{* *}$ & 0.0197 & 0.0129 \\
\hline & $(0.00941)$ & $(0.0115)$ & $(0.0102)$ & $(0.00931)$ & $(0.0176)$ & $(0.0102)$ & $(0.0123)$ & $(0.0115)$ \\
\hline \multirow[t]{2}{*}{ Gov/Y96 } & -0.0102 & 0.00669 & -0.00714 & -0.00542 & -0.0330 & 0.0130 & -0.0149 & 0.0139 \\
\hline & $(0.0144)$ & $(0.0167)$ & $(0.0150)$ & $(0.0136)$ & $(0.0315)$ & $(0.0154)$ & $(0.0184)$ & $(0.0199)$ \\
\hline \multirow[t]{2}{*}{ open $_{96}$} & 0.00237 & -0.000483 & 0.000227 & $0.00490^{* *}$ & $0.0209^{*}$ & -0.00418 & 0.000529 & -0.00523 \\
\hline & $(0.00322)$ & $(0.00394)$ & $(0.00575)$ & $(0.00238)$ & $(0.0120)$ & $(0.00666)$ & $(0.00433)$ & $(0.00770)$ \\
\hline \multirow[t]{2}{*}{ Justice 96} & 0.174 & & & & & & & \\
\hline & $(0.133)$ & & & & & & & \\
\hline \multirow[t]{2}{*}{ PropertyRights96 } & & $0.489^{* *}$ & & & & & & \\
\hline & & $(0.218)$ & & & & & & \\
\hline \multirow[t]{2}{*}{ LegalSystem $_{96}$} & & & $0.398^{* *}$ & & & & & \\
\hline & & & $(0.186)$ & & & & & \\
\hline \multirow[t]{2}{*}{ MostPeople $96_{96}$} & & & & $0.223^{*}$ & & & & \\
\hline & & & & $(0.128)$ & & & & \\
\hline \multirow[t]{2}{*}{ GovernmentPolicy } & & & & & -1.115 & & & \\
\hline & & & & & $(0.814)$ & & & \\
\hline \multirow[t]{2}{*}{ Government96 } & & & & & & $0.379^{*}$ & & \\
\hline & & & & & & $(0.221)$ & & \\
\hline \multirow[t]{2}{*}{ PoliticalParty $1_{02}$} & & & & & & & 0.448 & \\
\hline & & & & & & & $(0.405)$ & \\
\hline \multirow[t]{2}{*}{ PoliticalParty2 $2_{96}$} & & & & & & & & 0.416 \\
\hline & & & & & & & & $(0.262)$ \\
\hline \multirow[t]{2}{*}{ Constant } & $9.604^{* * *}$ & $10.99^{* * *}$ & $5.746^{* *}$ & $8.736^{* * *}$ & $14.22^{* * *}$ & 3.706 & $9.279^{* * *}$ & 3.309 \\
\hline & (2.213) & (2.551) & (2.517) & (1.961) & $(5.050)$ & (2.961) & (1.975) & (3.415) \\
\hline bservations & 46 & 46 & 42 & 46 & 46 & 35 & 46 & 35 \\
\hline
\end{tabular}

Notes: The dependent variable is the average growth rate of real GDP per capita during 1997-2012.

Heteroskedasticity robust standard error in parentheses. Levels of significance: *** $1 \%$, ** $5 \%$, * 10 $\%$. This table displays the second stage estimation results of the 2SLS method. Regional dummy variables (East_asia, Nordic) are included in the first stage. 
Table A11: Links from Institutional Trust to Growth (Cross-sectional OLS)

\begin{tabular}{|c|c|c|c|c|c|c|c|c|c|}
\hline & \multicolumn{6}{|c|}{ Schooling channel } & \multirow{2}{*}{\multicolumn{3}{|c|}{$\begin{array}{c}\text { Investment channel } \\
\begin{array}{l}\text { Investment share of GDP } \\
\text { (average of 1997-2010) }\end{array}\end{array}$}} \\
\hline \multirow{2}{*}{$\begin{array}{l}\text { Dep. Variables= } \\
\text { VARIABLES }\end{array}$} & \multicolumn{3}{|c|}{$\begin{array}{c}\text { Secondary School } \\
\text { Enrollment Rate } \\
\text { (Average of 2000-2010) }\end{array}$} & \multicolumn{3}{|c|}{$\begin{array}{c}\text { Years of Schooling } \\
\text { (Average of 2000-2010) }\end{array}$} & & & \\
\hline & (1) & (2) & (3) & (4) & (5) & (6) & (7) & (8) & (9) \\
\hline $\ln Y_{96}$ & $\begin{array}{l}3.956^{*} \\
(2.262)\end{array}$ & $\begin{array}{c}6.688^{* * *} \\
(2.405)\end{array}$ & $\begin{array}{l}4.711^{*} \\
(2.395)\end{array}$ & $\begin{array}{c}0.834^{* * *} \\
(0.220)\end{array}$ & $\begin{array}{c}1.078^{* * *} \\
(0.177)\end{array}$ & $\begin{array}{c}0.799^{* * *} \\
(0.205)\end{array}$ & $\begin{array}{c}1.570 \\
(1.036)\end{array}$ & $\begin{array}{c}0.956 \\
(0.950)\end{array}$ & $\begin{array}{c}2.702^{* * *} \\
(0.795)\end{array}$ \\
\hline Fertility 96 & $\begin{array}{l}-7.068 \\
(4.333)\end{array}$ & $\begin{array}{l}-6.456 \\
(4.229)\end{array}$ & $\begin{array}{c}-8.834^{*} \\
(5.033)\end{array}$ & $\begin{array}{l}-0.541 \\
(0.418)\end{array}$ & $\begin{array}{l}-0.496 \\
(0.402)\end{array}$ & $\begin{array}{l}-0.790^{*} \\
(0.440)\end{array}$ & & & \\
\hline$P_{-}$inv 96 & & & & & & & $\begin{array}{c}-0.153^{* * *} \\
(0.0303)\end{array}$ & $\begin{array}{c}-0.152^{* * *} \\
(0.0258)\end{array}$ & $\begin{array}{c}-0.140^{* * *} \\
(0.0329)\end{array}$ \\
\hline Justice $_{96}$ & $\begin{array}{c}0.833 \\
(0.820)\end{array}$ & & & $\begin{array}{c}0.0377 \\
(0.0949)\end{array}$ & & & $\begin{array}{l}0.955^{* *} \\
(0.377)\end{array}$ & & \\
\hline PropertyRights96 & & $\begin{array}{l}-1.248 \\
(1.027)\end{array}$ & & & $\begin{array}{l}-0.151 \\
(0.0982)\end{array}$ & & & $\begin{array}{c}1.455^{* * *} \\
(0.300)\end{array}$ & \\
\hline LegalSystem96 & & & $\begin{array}{l}-0.247 \\
(1.115)\end{array}$ & & & $\begin{array}{l}-0.0950 \\
(0.102)\end{array}$ & & & $\begin{array}{l}0.784^{* *} \\
(0.372)\end{array}$ \\
\hline Constant & $\begin{array}{c}44.16 \\
(28.53)\end{array}$ & $\begin{array}{c}29.59 \\
(27.46)\end{array}$ & $\begin{array}{c}46.51 \\
(32.64)\end{array}$ & $\begin{array}{c}3.013 \\
(2.738)\end{array}$ & $\begin{array}{l}1.753 \\
(2.292)\end{array}$ & $\begin{array}{c}4.471 \\
(2.905)\end{array}$ & $\begin{array}{l}16.81^{* *} \\
(7.544)\end{array}$ & $\begin{array}{c}19.34^{* * *} \\
(6.960)\end{array}$ & $\begin{array}{c}6.634 \\
(5.714)\end{array}$ \\
\hline Observations & 46 & 46 & 42 & 46 & 46 & 42 & 46 & 46 & 42 \\
\hline R-squared & 0.343 & 0.356 & 0.373 & 0.508 & 0.532 & 0.555 & 0.332 & 0.540 & 0.230 \\
\hline
\end{tabular}

Notes: Heteroskedasticity robust standard error in parentheses. Levels of significance: *** $1 \%, * * 5 \%$, * $10 \%$. This table examines the channels through which institutional trust affects economic outcomes. It shows that the investment channel is significant while the schooling channel is not. Results in columns (1)-(6) test if institutional trust (Justice, PropertyRights, \& LegalSystem) affects subsequent schooling outcomes such as the secondary school enrollment rate or years of schooling. Results in columns (7)-(9) test if institutional trust affects the subsequent investment/GDP ratio. Schooling data are from Barro and Lee (2010). Fertility data are from the World Bank database. Investment share of GDP is from Heston et al. (2012). 
Table A12: Determinants of Institutional Trust and Interpersonal Trust in a Cross-section of 46 Countries (OLS)

\begin{tabular}{|c|c|c|c|}
\hline \multirow[t]{2}{*}{ Dep. Var. $=$} & $\begin{array}{l}\text { Justice } \\
\text { (average 1997-2006) }\end{array}$ & $\begin{array}{c}\text { PropertyRights } \\
\text { (average1997-2006) }\end{array}$ & $\begin{array}{c}\text { MostPeople } \\
\text { (2005-2009wave) }\end{array}$ \\
\hline & (1) & (2) & (3) \\
\hline \multirow[t]{2}{*}{$\ln Y_{96}$} & $0.872^{* * *}$ & $0.693^{* * *}$ & 0.295 \\
\hline & $(0.240)$ & $(0.243)$ & $(0.311)$ \\
\hline \multirow[t]{2}{*}{ PRS rule-of-law96 } & $3.513^{* *}$ & $6.044^{* * *}$ & 0.291 \\
\hline & (1.681) & (1.502) & (2.348) \\
\hline \multirow[t]{2}{*}{ Hierarchical 70} & $-2.280^{* * *}$ & $-1.337^{* *}$ & $-2.309^{* * *}$ \\
\hline & (0.592) & $(0.604)$ & $(0.580)$ \\
\hline \multirow[t]{2}{*}{ Schoolg5 } & -0.00218 & -0.0212 & 0.00921 \\
\hline & $(0.0145)$ & (0.0133) & $(0.0124)$ \\
\hline \multirow[t]{2}{*}{ Ethnic Diversity ${ }_{1990 s}$} & 1.298 & 0.600 & 0.693 \\
\hline & (0.960) & $(1.066)$ & $(0.956)$ \\
\hline \multirow[t]{2}{*}{ Ginimid $_{1990 s}$} & -0.0128 & -0.0232 & $-0.0648^{*}$ \\
\hline & $(0.0211)$ & (0.0268) & $(0.0331)$ \\
\hline \multirow[t]{2}{*}{ Constant } & $-4.152^{*}$ & -2.958 & 4.640 \\
\hline & (2.415) & (2.588) & (2.766) \\
\hline Observations & 46 & 46 & 46 \\
\hline R-squared & 0.693 & 0.676 & 0.563 \\
\hline
\end{tabular}

Notes: Heteroskedasticity robust standard error in parentheses. Levels of significance: ${ }^{* * *} 1 \%, * * 5 \%$, $10 \%$. The dependent variable is institutional trust. This table shows that initial income level, the quality of institutions (PRS rule-of-law), and the proportion of hierarchical religions are main predictors of institutional trust in a cross-section of 46 countries.

Data sources: Justice and PropertyRights are from the IMD survey. Sources of InY, Hierarchical, School are reported in Table A2. PRS rule-of-law is from Political Risk Services (PRS). The Gini index is from World Bank database. Ethnic Diversity data are from Alesina et al. (2003). In the case of MostPeople, when 2005-2009 wave data are not available, data from other waves are used. 


\section{Table A13: Determinants of Institutional Trust in a Panel Of Countries}

\begin{tabular}{|c|c|c|c|c|c|c|c|c|}
\hline \multirow[b]{2}{*}{ Dep. Var. $=$} & \multicolumn{4}{|c|}{ Fixed Effect Model } & \multicolumn{2}{|c|}{$\begin{array}{c}\text { System GMM } \\
\text { estimator (1-step) }\end{array}$} & \multicolumn{2}{|c|}{$\begin{array}{c}\text { System GMM } \\
\text { estimator (2-step) }\end{array}$} \\
\hline & $\begin{array}{c}(1) \\
\text { Justice }_{, t}\end{array}$ & $\begin{array}{l}\text { (2) } \\
\text { Property } \\
\text { Rights } s_{i t}\end{array}$ & $\begin{array}{c}(3) \\
\text { Justice }: t\end{array}$ & $\begin{array}{l}\text { (4) } \\
\text { Property } \\
\text { Rights }, t\end{array}$ & $\begin{array}{c}(5) \\
\text { Justice }_{i, t}\end{array}$ & $\begin{array}{l}\text { (6) } \\
\text { Property } \\
\text { Rightisit }\end{array}$ & $\begin{array}{c}\text { (7) } \\
\text { Justice }_{: t}\end{array}$ & $\begin{array}{c}\text { (8) } \\
\text { Property } \\
\text { Rights } s_{i t}\end{array}$ \\
\hline PRS rule-of-lawit & $\begin{array}{l}0.801^{*} \\
(0.469)\end{array}$ & $\begin{array}{l}2.016^{* *} \\
(0.964)\end{array}$ & $\begin{array}{l}1.363^{*} \\
(0.733)\end{array}$ & $\begin{array}{l}4.115^{* *} \\
(1.540)\end{array}$ & $\begin{array}{c}2.273^{* * *} \\
(0.574)\end{array}$ & $\begin{array}{c}1.948^{* * *} \\
(0.560)\end{array}$ & $\begin{array}{c}2.021^{* * *} \\
(0.271)\end{array}$ & $\begin{array}{c}1.740^{* * *} \\
(0.211)\end{array}$ \\
\hline Growth $_{i, t}$ & $\begin{array}{c}0.0623^{* * *} \\
(0.0204)\end{array}$ & $\begin{array}{c}0.0747^{* * *} \\
(0.0249)\end{array}$ & $\begin{array}{c}0.0765^{* * *} \\
(0.0178)\end{array}$ & $\begin{array}{l}0.117^{* * *} \\
(0.0255)\end{array}$ & $\begin{array}{l}0.0619^{* *} \\
(0.0276)\end{array}$ & $\begin{array}{l}0.118^{* * *} \\
(0.0283)\end{array}$ & $\begin{array}{c}0.0657^{* * *} \\
(0.0121)\end{array}$ & $\begin{array}{c}0.0959^{* * *} \\
(0.0110)\end{array}$ \\
\hline Political Stability $y_{i, t}$ & $\begin{array}{l}-1.787 \\
(1.141)\end{array}$ & $\begin{array}{l}-1.786 \\
(1.139)\end{array}$ & $\begin{array}{l}-2.169 \\
(2.192)\end{array}$ & $\begin{array}{l}-1.798 \\
(3.183)\end{array}$ & $\begin{array}{l}-0.710 \\
(1.162)\end{array}$ & $\begin{array}{l}-1.374 \\
(1.120)\end{array}$ & & \\
\hline Ginn $_{i, t}$ & & & $\begin{array}{c}-0.0446^{*} \\
(0.0242)\end{array}$ & $\begin{array}{r}-0.00227 \\
(0.0234)\end{array}$ & & & & \\
\hline Justice $_{i, t-1}$ & & & & & $\begin{array}{l}0.703^{* * *} \\
(0.0682)\end{array}$ & & $\begin{array}{l}0.740^{* * *} \\
(0.0302)\end{array}$ & \\
\hline PropertyRights $s_{i,-1}$ & & & & & & $\begin{array}{l}0.776^{* * *} \\
(0.0698)\end{array}$ & & $\begin{array}{l}0.800^{* * *} \\
(0.0192)\end{array}$ \\
\hline Country Fixed Effects & Yes & Yes & Yes & Yes & Yes & Yes & Yes & Yes \\
\hline Time dummies & Yes & Yes & Yes & Yes & Yes & Yes & Yes & Yes \\
\hline serrial correlation te & est ( $p$-valu & & & & 0.2724 & 0.0868 & 0.2571 & 0.0517 \\
\hline Sargan test on ove & ID restric & tions ( $p-v e$ & alue $)^{b}$ & & 0.1033 & 0.3272 & 0.1776 & 0.4127 \\
\hline R-squared & 0.137 & 0.315 & 0.217 & 0.400 & - & - & - & - \\
\hline Countries $(\mathrm{N})$ & 46 & 46 & 12 & 12 & 46 & 46 & 46 & 46 \\
\hline Observations (NxT) & 230 & 230 & 60 & 60 & 184 & 184 & 184 & 184 \\
\hline
\end{tabular}

Notes: Heteroskedasticity and country-specific autocorrelation consistent t-statistics are in parentheses. Time dummies and fixed effect terms are not reported. Levels of significance: *** $1 \%, * * 5 \%, 10 \%$. This table displays the estimation results of the fixed effect panel model ((1)-(4)) and Arellano and Bover (1995) / Blundell and Bond's (1998) system GMM estimator ((5)-(8)). The dependent variable is the 4-year average of institutional trust during 1993 2012. All explanatory variables are also based on the 4-year average figure for the same period whenever data are available. Hence, the panel data has 230 observations ( $T=5, N=46$ ). (When the GMM method is applied, the number of observations decreases because lagged variables are used as instruments.) Note that the coefficients of the lagged dependent variable in (5)-(8) are large and significant, which indicates that (i) there is a large persistent component in institutional trust, which is consistent with the cross-sectional result that shows time-invariant factors affect institutional trust and (ii) employing the System GMM improves the efficiency and consistency of estimators. In the System GMM estimation, all explanatory variables except for time dummies are assumed to be endogenous and hence instrumented by instrumental variables. Time dummies are assumed to be strictly exogenous, which is a standard assumption in the dynamic panel model. Sources of data are reported in Table A2. Political Stability Index is the PRS indicator for Political Stability and Absence of Violence.

a) The null hypothesis is that the first-differenced errors exhibit no second-order serial correlation. For example, the result in column (5) says that one cannot reject the null hypothesis of no second-order serial correlation as the $p$-value is 0.2724 .

b) The null hypothesis is that instruments are not correlated with the error term (vi,t). For example, the result in column (5) says that one cannot reject the null hypothesis that orthogonality conditions are valid as the $p$-value is 0.1033 


\section{$<$ Abstract in Korean $>$}

\section{신뢰의 유형과 경제성장에 관한 연구: 사람·제도·정치에 대한 신뢰를 중심으로}

많은 연구들이 신뢰(trust)가 경제성장에 중요 요소임을 보여주고 있으나 대인 신뢰에 한정하여 분석해 왔다. 본고는 다양한 유형의 신뢰 - 사람에 대한 신뢰 (대인 신뢰), 제도에 대한 신뢰(예: 공정한 법집행에 대한 신뢰, 재산권 보호에 대한 신뢰), 정치에 대한 신뢰(예: 정부, 정당에 대한 신뢰)-를 고려하고, 각 유형의 신뢰가 성장에 미치는 영향에 대해 연구하였다. 46 개국 서베이 데이터를 이용한 국가간 횡단면 분석 결과, 제도에 대한 신뢰가 경제 성장과 가장 강건하게 연관 되어 있음을 본고는 확인하였다. 46 개국 패널 데이타를 이용한 분석에서는, '제도에 대한 신뢰 $\rightarrow$ 경제성장'의 인과관계(causal relationship)가 있음을 확인 하였다. 따라서 기존 문헌들이 '사람'에 대한 신뢰의 중요성을 강조하고 동 신뢰를 ‘변하지 않는 문화적인 요소'로 간주한 데 반해, 본 연구는 '사회 시스템'에 대한 신뢰가 중요하며 이것은 '제도 (institutions)에 의해 결정될 수 있는 요소' 임을 강조하고 있다.

핵심 주제어: 제도와 경제성장, 신뢰, 사회적 자본

JEL Classification: O17, P16, Z13

* 한 국은행 경제연구원 금융통화연구실 부연구위원 (전화: 02-759-5362, E-mail: hid@bok.or.kr) 


\section{$\mathrm{BOK}$ 경제연구 발간목록}

한국은행 경제연구원에서는 Working Paper인 『BOK 경제연구』를 수시로 발간하고 있습니다. 『BOK 경제연구』는 주요 경제 현상 및 정책 효과에 대한 직관적 설명 뿐 아니라 깊이 있는 이론 또는 실증 분석을 제공함으로써 엄밀한 논증에 초점을 두는 학술논문 형태의 연구이며 한국은행 직원 및 한국은행 연구용역사업의 연구 결과물이 수록되고 있습니다.

${ }^{\circledR} \mathrm{BOK}$ 경제연구』 는 한국은행 경제연구원 홈페이지(http://imer.bok.or.kr)에서 다운로드하여 보실 수 있습니다.

제2014-1 Network Indicators for Monitoring Intraday Liquidity in BOK-Wire+

2 중소기업에 대한 신용정책 효과

3 경제충격 효과의 산업간 공행성 분석

4 서비스업 발전을 통한 내외수 균형성장: 기대효과 및 리스크

5 Cross-country-heterogeneous and Time-varying Effects of Unconventional Monetary Policies in AEs on Portfolio Inflows to EMEs

6 인터넷뱅킹, 결제성예금 및 은행 수익성과의 관계 분석

7 Dissecting Foreign Bank Lending Behavior During the 2008-2009 Crisis

8 The Impact of Foreign Banks on Monetary Policy Transmission during the Global Financial Crisis of 2008-2009: Evidence from Korea

9 Welfare Cost of Business Cycles in Economies with Individual Consumption Risk

10 Investor Trading Behavior Around the Time of Geopolitical Risk Events: Evidence from South Korea

11 Imported-Inputs Channel of Exchange Rate Pass-Through: Evidence from Korean Firm-Level Pricing Survey
Seungjin Baek

Kimmo Soram ki . Jaeho Yoon

정호성·임호성

황선웅·민성환 ·

신동현 · 김기호

김승원 · 황광명

Kyoungsoo Yoon •

Christophe Hurlin

이동규·전봉걸

Moon Jung Choi •

Eva Gutierrez •

Maria Soledad Martinez Peria

Bang Nam Jeon •

Hosung Lim. Ji Wu

Martin Ellison •

Thomas J. Sargent

Young Han Kim •

Hosung Jung

Jae Bin Ahn -

Chang-Gui Park 


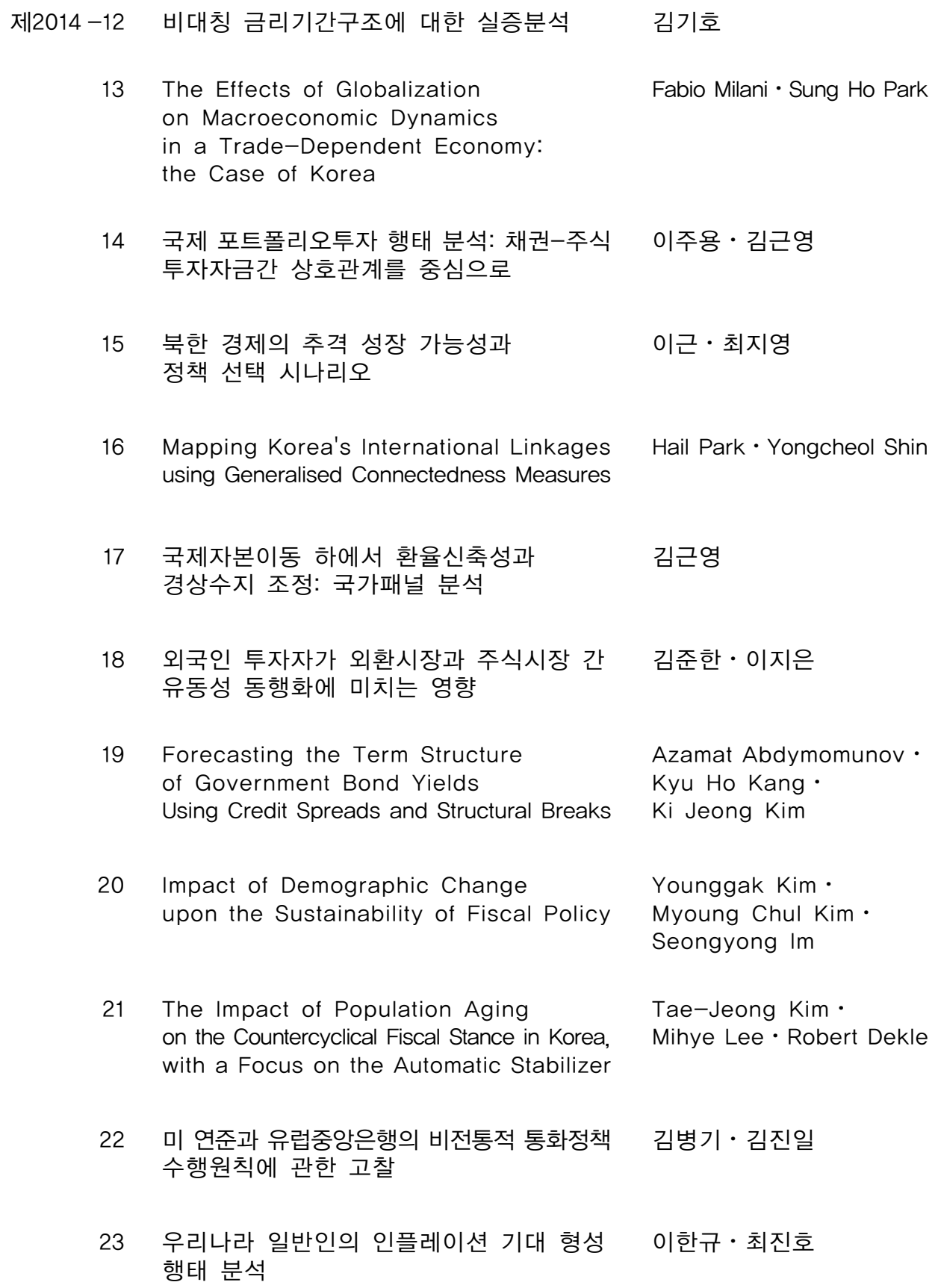

16 Mapping Korea's International Linkages using Generalised Connectedness Measures

17 국제자본이동 하에서 환율신축성과 경상수지 조정: 국가패널 분석

이주용·김근영

이근·최지영

Hail Park $\cdot$ Yongcheol Shin

18 외국인 투자자가 외환시장과 주식시장 간 유동성 동행화에 미치는 영향

19 Forecasting the Term Structure of Government Bond Yields Using Credit Spreads and Structural Breaks

20 Impact of Demographic Change upon the Sustainability of Fiscal Policy

21 The Impact of Population Aging on the Countercyclical Fiscal Stance in Korea, with a Focus on the Automatic Stabilizer

김근영

김준한 $\cdot$ 이지은

Azamat Abdymomunov •

Kyu Ho Kang.

Ki Jeong Kim

Younggak Kim •

Myoung Chul Kim.

Seongyong Im

Tae-Jeong Kim $\cdot$

Mihye Lee $\cdot$ Robert Dekle

22 미 연준과 유럽중앙은행의 비전통적 통화정책 수행원칙에 관한 고찰

김병기·김진일

23 우리나라 일반인의 인플레이션 기대 형성 행태 분석

이한규・최진호 
제2014-24 Nonlinearity in Nexus between

Working Hours and Productivity

25 Strategies for Reforming Korea's Labor Market to Foster Growth

26 글로벌 금융위기 이후 성장잠재력 확충: 2014 한국은행 국제컨퍼런스 결과보고서

27 인구구조 변화가 경제성장률에 미치는 영향: 자본이동의 역할에 대한 논의를 중심으로

28 Safe Assets

29 확장된 실업지표를 이용한 우리나라 노동시장에서의 이력현상 분석

Entropy of Global Financial Linkages

31 International Currencies Past, Present and Future: Two Views from Economic History

32 금융체제 이행 및 통합 사례:

남북한 금융통합에 대한 시사점

Measuring Price-Level Uncertainty and Instability in the U.S., 1850-2012

고용보호제도가 노동시장 이원화

및 노동생산성에 미치는 영향

35 해외충격시 외화예금의 역할 : 주요 신흥국 신용스프레드에 미치는 영향을 중심으로 Emerging Market Economies, and Their Policy Responses
Dongyeol Lee •

Hyunjoon Lim

Mai Dao · Davide Furceri ·

Jisoo Hwang .

Meeyeon Kim •

Tae-Jeong Kim

한국은행 경제연구원

손종칠

Robert J. Barro

김현학 · 황광명

Daeyup Lee

Barry Eichengreen

김병연

Timothy Cogley •

Thomas J. Sargent

김승원

정호성 - 우준명

김인수 · 이명수

황광명 · 김경민 ·

노충식·김미진

Woon Gyu Choi •

Taesu Kang •

Geun-Young Kim •

Byongju Lee 
제2015-1 글로벌 금융위기 이후 주요국

통화정책 운영체계의 변화

2 미국 장기시장금리 변동이 우리나라 금리기간구조에 미치는 영향 분석 및 정책적 시사점

3 직간접 무역연계성을 통한 해외충격의 우리나라 수출입 파급효과 분석

4 통화정책 효과의 지역적 차이

5 수입중간재의 비용효과를 고려한 환율변동과 수출가격 간의 관계

6 중앙은행의 정책금리 발표가 주식시장 유동성에 미치는 영향

7 은행 건전성지표의 변동요인과 거시건전성 규제의 영향

8 Price Discovery and Foreign Participation in The Republic of Korea's Government Bond Futures and Cash Markets

9 규제가 노동생산성에 미치는 영향:

한국의 산업패널 자료를 이용한 실증분석

10 인구 고령화와 정년연장 연구

(세대 간 중첩모형(OLG)을 이용한 정량 분석)

11 예측조합 및 밀도함수에 의한 소비자물가 상승률 전망

12 인플레이션 동학과 통화정책

13 Failure Risk and the Cross-Section of Hedge Fund Returns

14 Global Liquidity and Commodity Prices

15 Foreign Ownership, Legal System and Stock Market Liquidity
김병기·김인수

강규호·오형석

최문정·김근영

김기호

김경민

이지은

강종구

Jaehun Choi - Hosung Lim •

Rogelio Jr. Mercado •

Cyn-Young Park

이동렬 - 최종일 - 이종한

홍재화 - 강태수

김현학

우준명

Jung-Min Kim

Hyunju Kang ·

Bok-Keun $\mathrm{Yu}$.

Jongmin $\mathrm{Yu}$

Jieun Lee $\cdot$ Kee H. Chung 
제2015-16 바젤피 은행 경기대응완충자본 규제의 기준지표에 대한 연구

17 우리나라 대출 수요와 공급의 변동요인 분석

18 북한 인구구조의 변화 추이와 시사점

19 Entry of Non-financial Firms and Competition in the Retail Payments Market

20 Monetary Policy Regime Change and Regional Inflation Dynamics: Looking through the Lens of Sector-Level Data for Korea

21 Costs of Foreign Capital Flows in Emerging Market Economies: Unexpected Economic Growth and Increased Financial Market Volatility

22 글로벌 금리 정상화와 통화정책 과제: 2015년 한국은행 국제컨퍼런스 결과보고서

23 The Effects of Global Liquidity on Global Imbalances

24 실물경기를 고려한 내재 유동성 측정

25 Deflation and Monetary Policy

26 Macroeconomic Shocks and Dynamics of Labor Markets in Korea

27 Reference Rates and Monetary Policy Effectiveness in Korea

29 An Analysis of Trade Patterns in East Asia and the Effects of the Real Exchange Rate Movements

30 Forecasting Financial Stress Indices in Korea: A Factor Model Approach
서현덕·이정연

강종구 · 임호성

최지영

Jooyong Jun

Chi-Young Choi •

Joo Yong Lee

Roisin O'Sullivan

Kyoungsoo Yoon • Jayoung Kim

한국은행 경제연구원

Marie-Louise DJIGBENOU-KRE •

Hail Park

우준명·이지은

Barry Eichengreen

Tae Bong Kim •

Hangyu Lee

Heung Soon Jung •

Dong Jin Lee.

Tae Hyo Gwon .

Se Jin Yun

Bongseok Choi •

Wooyoung Park.

Bok-Keun Yu

Moon Jung Choi

Geun-Young Kim • Joo Yong Lee

Hyeongwoo Kim $\cdot$ Hyun Hak Kim. Wen Shi 


\begin{tabular}{|c|c|c|}
\hline 제2016 -1 & $\begin{array}{l}\text { The Spillover Effects of U.S. Monetary } \\
\text { Policy on Emerging Market Economies: } \\
\text { Breaks, Asymmetries and } \\
\text { Fundamentals }\end{array}$ & $\begin{array}{l}\text { Geun-Young Kim } \\
\text { Hail Park } \\
\text { Peter Tillmann }\end{array}$ \\
\hline 2 & $\begin{array}{l}\text { Pass-Through of Imported Input Prices } \\
\text { to Domestic Producer Prices: Evidence } \\
\text { from Sector-Level Data }\end{array}$ & $\begin{array}{l}\text { JaeBin Ahn } \\
\text { Chang-Gui Park } \\
\text { Chanho Park }\end{array}$ \\
\hline 3 & $\begin{array}{l}\text { Spillovers from U.S. Unconventional } \\
\text { Monetary Policy and Its Normalization } \\
\text { to Emerging Markets: A Capital Flow } \\
\text { Perspective }\end{array}$ & $\begin{array}{l}\text { Sangwon Suh } \\
\text { Byung-Soo Koo }\end{array}$ \\
\hline 4 & $\begin{array}{l}\text { Stock Returns and Mutual Fund Flows } \\
\text { in the Korean Financial Market: } \\
\text { A System Approach }\end{array}$ & $\begin{array}{l}\text { Jaebeom Kim } \\
\text { Jung-Min Kim }\end{array}$ \\
\hline 5 & $\begin{array}{l}\text { 정책금리 변동이 성별·세대별 고용률에 } \\
\text { 미치는 영향 }\end{array}$ & 정성엽 \\
\hline 6 & $\begin{array}{l}\text { From Firm-level Imports to Aggregate } \\
\text { Productivity: Evidence from Korean } \\
\text { Manufacturing Firms Data }\end{array}$ & $\begin{array}{l}\text { JaeBin Ahn } \\
\text { Moon Jung Choi }\end{array}$ \\
\hline 7 & $\begin{array}{l}\text { 자유무역협정(FTA)이 한국 기업의 } \\
\text { 기업내 무역에 미친 효과 }\end{array}$ & 전봉걸·김은숙·이주용 \\
\hline 8 & $\begin{array}{l}\text { The Relation Between Monetary and } \\
\text { Macroprudential Policy }\end{array}$ & Jong Ku Kang \\
\hline 9 & $\begin{array}{l}\text { 조세피난처 투자자가 투자 기업 및 주식 } \\
\text { 시장에 미치는 영향 }\end{array}$ & 정호성·김순호 \\
\hline 10 & $\begin{array}{l}\text { 주택실거래 자료를 이용한 주택부문 거시 } \\
\text { 건전성 정책 효과 분석 }\end{array}$ & 정호성·이지은 \\
\hline 11 & $\begin{array}{l}\text { Does Intra-Regional Trade Matter in } \\
\text { Regional Stock Markets?: New } \\
\text { Evidence from Asia-Pacific Region }\end{array}$ & $\begin{array}{l}\text { Sei-Wan Kim } \cdot \\
\text { Moon Jung Choi }\end{array}$ \\
\hline 12 & $\begin{array}{l}\text { Liability, Information, and Anti-fraud } \\
\text { Investment in a Layered Retail } \\
\text { Payment Structure }\end{array}$ & $\begin{array}{l}\text { Kyoung-Soo Yoon } \\
\text { Jooyong Jun }\end{array}$ \\
\hline 13 & $\begin{array}{l}\text { Testing the Labor Market Dualism in } \\
\text { Korea }\end{array}$ & $\begin{array}{l}\text { Sungyup Chung } \\
\text { Sunyoung Jung }\end{array}$ \\
\hline 14 & $\begin{array}{l}\text { 북한 이중경제 사회계정행렬 추정을 통한 } \\
\text { 비공식부문 분석 }\end{array}$ & 최지영 \\
\hline
\end{tabular}




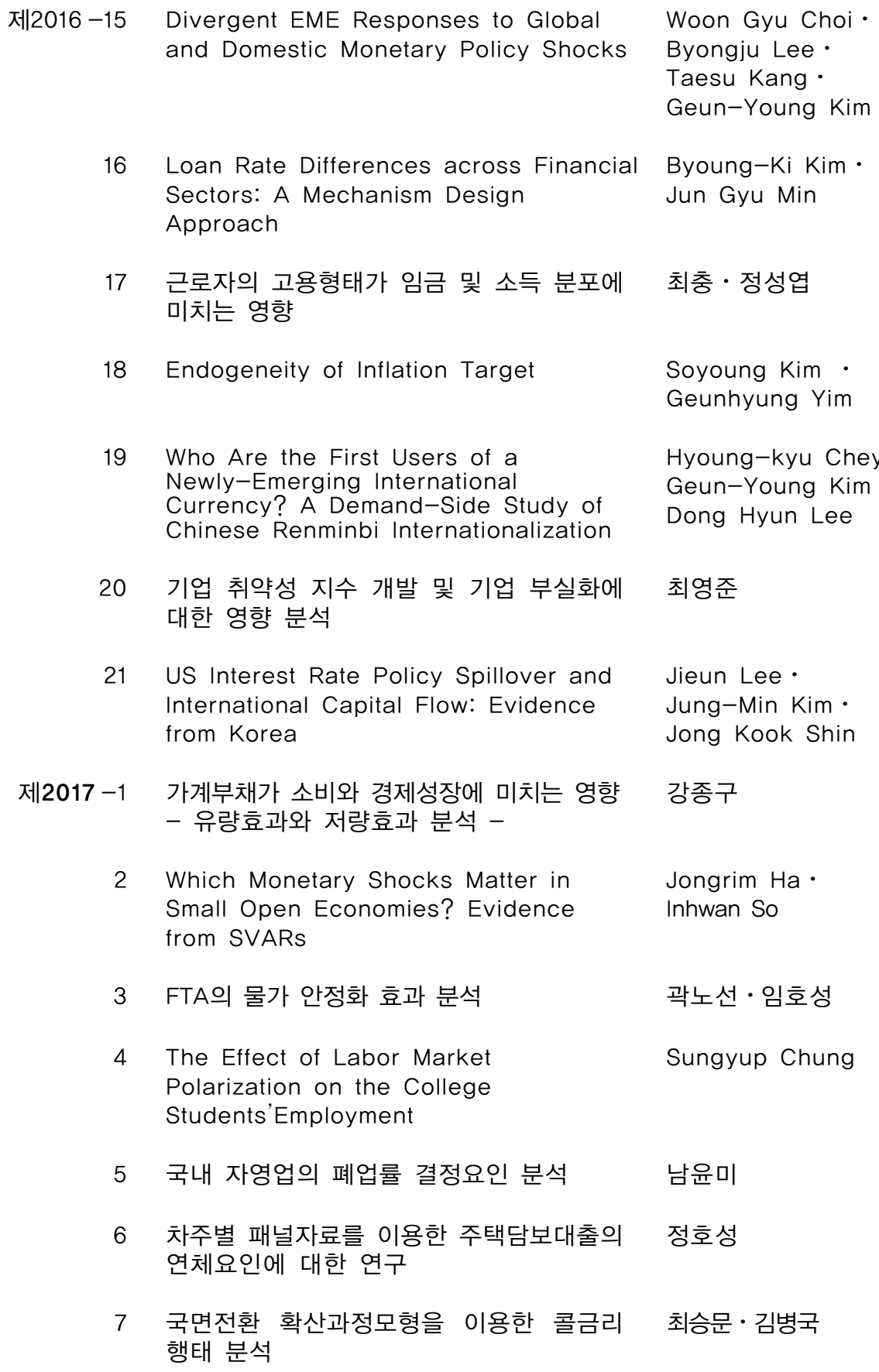

20 기업 취약성 지수 개발 및 기업 부실화에 최영준 대한 영향 분석

21 US Interest Rate Policy Spillover and International Capital Flow: Evidence from Korea

Jieun Lee Jung-Min Kim • Jong Kook Shin

제2017-1 가계부채가 소비와 경제성장에 미치는 영향 강종구

- 유량효과와 저량효과 분석 -

2 Which Monetary Shocks Matter in Small Open Economies? Evidence from SVARs

Jongrim $\mathrm{Ha} \cdot$ Inhwan So

3 FTA의 물가 안정화 효과 분석

곽노선·임호성

4 The Effect of Labor Market

Sungyup Chung

Polarization on the College Students'Employment

5 국내 자영업의 폐업률 결정요인 분석 남윤미

6 차주별 패널자료를 이용한 주택담보대출의 정호성 연체요인에 대한 연구

7 국면전환 확산과정모형을 이용한 콜금리 최승문·김병국 행태 분석 


\begin{tabular}{|c|c|c|}
\hline 제2017 -8 & $\begin{array}{l}\text { Behavioral Aspects of Household } \\
\text { Portfolio Choice: Effects of Loss } \\
\text { Aversion on Life Insurance Uptake } \\
\text { and Savings }\end{array}$ & In Do Hwang \\
\hline 9 & 신용공급 충격이 재화별 소비에 미치는 영향 & 김광환 · 최석기 \\
\hline 10 & 유가가 손익분기인플레이션에 미치는 영향 & 김진용·김준철·임형준 \\
\hline 11 & $\begin{array}{l}\text { 인구구조변화가 인플레이션의 장기 } \\
\text { 추세에 미치는 영향 }\end{array}$ & 강환구 \\
\hline 12 & $\begin{array}{l}\text { 종합적 상환여건을 반영한 과다부채 } \\
\text { 가계의 리스크 요인 분석 }\end{array}$ & 이동진·한진현 \\
\hline 13 & $\begin{array}{l}\text { Crowding out in a Dual Currency Regime? } \\
\text { Digital versus Fiat Currency }\end{array}$ & $\begin{array}{l}\text { KiHoon Hong } \cdot \\
\text { Kyounghoon Park } \\
\text { Jongmin } \mathrm{Yu}\end{array}$ \\
\hline 14 & $\begin{array}{l}\text { Improving Forecast Accuracy of } \\
\text { Financial Vulnerability: Partial Least } \\
\text { Squares Factor Model Approach }\end{array}$ & $\begin{array}{l}\text { Hyeongwoo Kim } \\
\text { Kyunghwan Ko }\end{array}$ \\
\hline 15 & $\begin{array}{l}\text { Which Type of Trust Matters?: } \\
\text { Interpersonal vs. Institutional vs. } \\
\text { Political Trust }\end{array}$ & In Do Hwang \\
\hline
\end{tabular}

